\title{
Primary processes in sensory cells: current advances
}

\author{
Stephan Frings
}

Received: 14 September 2008 / Revised: 25 October 2008 / Accepted: 25 October 2008 / Published online: 15 November 2008

(C) The Author(s) 2008. This article is published with open access at Springerlink.com

\begin{abstract}
In the course of evolution, the strong and unremitting selective pressure on sensory performance has driven the acuity of sensory organs to its physical limits. As a consequence, the study of primary sensory processes illustrates impressively how far a physiological function can be improved if the survival of a species depends on it. Sensory cells that detect single-photons, single molecules, mechanical motions on a nanometer scale, or incredibly small fluctuations of electromagnetic fields have fascinated physiologists for a long time. It is a great challenge to understand the primary sensory processes on a molecular level. This review points out some important recent developments in the search for primary processes in sensory cells that mediate touch perception, hearing, vision, taste, olfaction, as well as the analysis of light polarization and the orientation in the Earth's magnetic field. The data are screened for common transduction strategies and common transduction molecules, an aspect that may be helpful for researchers in the field.
\end{abstract}

Keywords Mechanoreception · Photoreception - Taste · Olfaction $\cdot$ Magnetoreception
Abbreviations
CNG Channel cyclic nucleotide-gated channel
$\mathrm{ENaC}$ Epithelial sodium channel
GARP Glutamic acid-rich protein
GPCR GTP-binding protein coupled receptor
IHC Inner hair cell

\footnotetext{
S. Frings $(\square)$

Department of Molecular Physiology,

University of Heidelberg, Im Neuenheimer Feld 230,

69120 Heidelberg, Germany

e-mail: s.frings@zoo.uni-heidelberg.de
}

\author{
INAD Inactivation no after-potential D \\ MEC Mechanosensitive channel-related protein \\ OHC Outer hair cell \\ ORN Olfactory receptor neuron \\ PDE Phosphodiesterase \\ PDZ Domain postsynaptic density/discs-large/zonula \\ occludens domain \\ TRP Channel transient receptor potential channel \\ VNO Vomeronasal organ
}

\section{Introduction}

Sensory cells provide the central nervous system with vital information about the body and its environment. Each sensory cell detects specific stimuli using highly specialized structures which operate as sensors for adequate stimuli. Thus, the posture of the body, its supply with nutrients and oxygen, the state of the cardiovascular and digestive systems, as well as the body temperature and ion concentrations are constantly monitored by a set of sensory cells. Moreover, information about objects in the environment, their shape, color, chemical composition, their distance and movement are collected and conveyed to the central nervous system. This steady and complex flow of coded information is then integrated and used to generate sensible behavior.

Sensory cells display a multitude of remarkable adaptations towards their tasks. The adequate stimulus is detected by a sensor which must be both selective and sensitive. To detect weak stimuli that transfer only little energy to the sensory cell, primary signals have to be amplified and an output signal must be generated that can be interpreted by the brain. These primary processes constitute an efficient and characteristic transduction cascade in each type of 
sensory cell. In the evolution of animals, sensory acuity is continuously sharpened under intense selective pressure, and the transduction cascades are the prime targets of this process. The result is a set of cells with astonishing performance: photoreceptors that detect single-photons, mechanoreceptors that respond to the movements on a nanometer scale and chemoreceptors that report the detection of single molecules. Furthermore, the perception of electromagnetic radiation by many animal species amazes physiologists, and the research for the transduction mechanisms that mediate the analysis of infrared radiation, electrical fields or magnetic navigation cues is among the most exciting fields in sensory physiology. This review tries to provide a brief overview of current work on sensory transduction mechanisms. I focus on just one or a few research topics in each of the sensory modalities, and I try to point out the significance of recent findings for the scientific concepts of sensory function. The depth of knowledge and the accuracy of mechanistic models vary considerably between well-studied cells such as photoreceptors and more enigmatic cells like the touch receptors in the human skin. However, as common transduction features begin to appear, new experimental approaches become available which are based on the observation that various sensory cells use similar or homologous proteins for transduction. Thus, the examination of transduction channels or amplification mechanisms in one type of sensory cell may help to advance studies of transduction in a different modality. The present review is designed to promote such effects.

\section{Mechanoreceptors: tugging at enigmatic channels}

Touching an animal usually triggers rapid and robust motorresponses, ranging from twitching of the skin to violent startle responses. Oddly enough, this basic and omnipresent sense appears to be one of the most difficult to study on the level of its transduction mechanism. It is quite clear that mechanical stimuli of various sorts can trigger opening of ion channels and cause depolarization in practically every cell (Hamill and Martinac 2001; Kung 2005; Hamill 2006). However, sensory cells which are specialized for the detection of mechanical stimuli (mechanoreceptors) can use elaborate protein complexes to transduce adequate mechanical stimuli, and to report a sensory signal to the central nervous system. How intricate the structure of such a transducer can be revealed by an extensive genetic screen of Caenorhabditis elegans mutants which took more than 25 years and brought to light a set of proteins that coassemble to form a mechanotransduction complex (O'Hagan and Chalfie 2006; Bianchi 2007; Bounoutas and Chalfie 2007). This multi-protein system works by pulling transduction channels open when the worm's cuticula moves (Fig. 1). In the touch receptor neurons, transduction channels are tethered to the cuticula on the extracellular side of the plasma membrane and, possibly, to the cytoskeleton on the intracellular side. The channel itself is composed of two subunits, MEC-4 and MEC-10 (O'Hagan et al. 2005; Brown et al. 2008). MEC-4 and MEC-10 belong to the degenerin/ENaC family of cation channels (Tavernarakis and Driscoll 2001; Kellenberger and Schild 2002; Suzuki et al. 2003) and form the channel pore, while MEC-6 and MEC-2 are auxiliary subunits necessary for proper function of the MEC-4/MEC-10 channel (Chelur et al. 2002; Goodman et al. 2002; Brown et al. 2008). MEC-2 belongs to the large group of prohibitin homology (PHB-) domain proteins (Morrow and Parton 2005). MEC-2 is a cholesterol-binding protein and associates with the channel through its PHB domain, apparently within a cholesterol-rich lipid-raft like membrane environment (Zhang et al. 2004; Huber et al. 2006). A similar protein, UNC-24, is also associated with the transduction complex, but its role in channel regulation is less well understood. The touch receptor neurons possess rather thick microtubules consisting of 15 instead of the usual 11 protofilaments (Chalfie and Thomson 1982; Fukushige et al. 1999). MEC-7 and MEC-12 are necessary for the function of transduction complex, but it is not clear how the channel subunits connect to the microtubuli, if indeed such a cytoskeletal tethering of the transduction complex exists. The extracellular anchoring of the complex is well characterized (Du et al. 1996; Emtage et al. 2004). It involves a number of extracellular matrix proteins, at least three of which are associated with the transduction complex. MEC-5 is a unique collagen secreted by the epidermal cells of $C$. elegans, while MEC-1 and MEC-9 are matrix proteins with multiple proteininteraction domains. These proteins attach the transduction complex to the cuticula and may, therefore, play a critical

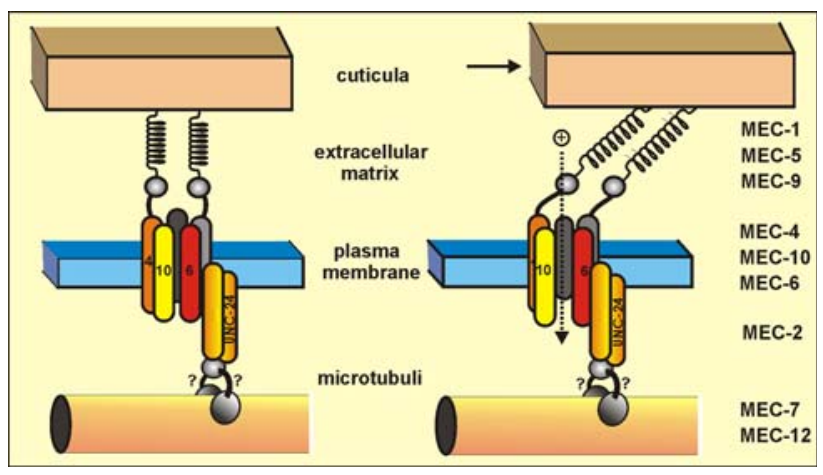

Fig. 1 The mechanosensitive protein complex of C. elegans. Left: nine different MEC proteins co-assemble to form an ion channel in the plasma membrane of a mechanosensory neuron. The channel is formed by MEC-4, MEC-6, and MEC-10. Other MEC proteins tether the channel to the cuticula and to the cytoskeleton. Right: when the cuticula is shifted by gentle touch, the channel is pulled open, and cation influx generates a receptor potential 
role in mechanotransduction. Moreover, they are necessary to concentrate the MEC-4/MEC-10 channels in characteristical punctate clusters in the membrane of touch receptors. Thus, the model in Fig. 1 illustrates the possible coordination of nine different MEC proteins to form a functional mechanotransducer. More proteins may contribute to this complex, and the list of potentially relevant proteins currently extends to MEC- 18 .

Mechanoreceptors in vertebrates are much less well understood, and there is a hope that the $C$. elegans touch receptor neuron will serve as a blueprint for a corresponding model composed of homologous vertebrate proteins. This approach has only just begun, but there are already promising results. A member of the PHB domain protein family, stomatin-like protein 3 (SLP3), turned out to be necessary for normal touch sensation in mice (Wetzel et al. 2007). The related protein stomatin is needed for sensory function in rapidly adapting D-hair mechanoreceptors (Martinez-Salgado et al. 2007). These findings suggest that SLP3 and stomatin play a similar role in vertebrate mechanotransduction as MEC-2 plays in the $C$. elegans touch receptor. Although it is too early to speculate the notion that vertebrate mechanotransducers are protein complexes with tethered transduction channels appears to be a reasonable working hypothesis. Future work may lead to the identification of multiple transduction components and to gene ablation experiments with unambiguous phenotypes. Up to now, the search for mechanotransduction channels has only produced conflicting results (Drew et al. 2004; Gottlieb et al. 2008), and the molecular identity of the channels remains elusive. An important question is whether lowthreshold touch receptors and high-threshold nociceptors use the same gating principle to generate mechanoreceptor potentials (Hu et al. 2006). A recent report on the effects on pain behavior of a spider toxin that blocks stretch-activated cation channels (GsMTx4; Park et al. 2008) suggested an involvement of transduction channels gated by membrane stretch. It is conceivable, although entirely speculative, that the detection of gentle touch relies on multi-protein transduction complexes in vertebrate touch receptor neurons, while nociceptors respond to their much stronger stimuli with simple stretch-sensitive channels. It is also possible that the C. elegans-type transduction complex and the stretch-sensitive channel do not represent mutually exclusive gating principles. There may be various intermediate structures with transduction channels attached to the cytoskeleton or to proteins in the membrane or the extracellular matrix. The challenge is to identify the channel protein itself, which can probably be done only by genetic means, because the proteins cannot be isolated from the fine sensory endings of mechanoreceptors. Once this is achieved, auxiliary subunits and associated proteins can be identified more easily.
A fascinating example of vertebrate mechanosensory transduction by tethered channels is the generation of receptor potentials in the hair cells of the inner ear. These exquisitely sensitive cells detect movements on a nanometer scale by their apical hair bundles and transmit the sensory signal to afferent neurons with high efficiency. Based on groundbreaking electrophysiological studies (Corey and Hudspeth 1979; Hudspeth 1982; Corey and Hudspeth 1983) and the discovery of protein filaments connecting the sterocilia within a hair bundle (Pickles et al. 1984; Furness and Hackney 1985), a working hypothesis was formulated that explained hair-cell function in terms of a tethered transduction channel (Pickles 1985; Holton and Hudspeth 1986; Hudspeth 1989). An impressive array of excellent biophysical investigations was since carried out to scrutinize and improve this hypothesis (recent reviews: Gillespie et al. 2005; Corey 2006; Fettiplace and Hackney 2006; Ricci et al. 2006; Grant and Fuchs 2007; Vollrath et al. 2007). Today, the tethered-channel hypothesis is well established, and much of the current work is focussed on identifying the molecular components of the transduction complex.

In the organ of Corti, the sensory inner hair cells (IHCs) extend their sensory stereocilia into a thin layer of endolymph between the top of the sensory epithelium and the tectorial membrane (Fig. 2a). Lateral movements of this fluid layer deflect the stereocilia when the Corti organ responds to sound with local vibrations. The hair bundle consists of 50-300 stereocilia which move together because various protein filaments connect each stereocilium to its neighbors. In fact, all stereocilia of a bundle move in unison so that the entire hair bundle acts as a functional unit (Kozlov et al. 2007). The tip of each stereocilium is connected to the lateral membrane of its larger neighbor by a protein filament called tip link (Fig. 2b). When the endolymph tilts the stereocilia along the tip-links' axis, the two attachment points of each tip link move slightly apart, stretching the protein filament. Two cell adhesion proteins, cadherin 23 (Siemens et al. 2004) and protocadherin 15 (Ahmed et al. 2006), co-assemble to form the $\sim 150 \mathrm{~nm}$ long tip-link filament (Kachar et al. 2000; Corey 2007; Kazmierczak et al. 2007; Furness et al. 2008; Müller 2008). Since both the setereocilia and the tip links appear to be rather stiff structures with low elasticity, each displacement of the hair bundle causes an immediate mechanical force to act on the two attachment points where it opens transduction channels. The resulting depolarization leads to the activation of ribbon synapses at the basal pole of the hair cell which transmit the signal with remarkable fidelity to multiple afferent neurons (Sterling and Matthews 2005; Nouvian et al. 2006). To ensure optimal operating conditions in all physiological situations, the hair cell actively adjusts the tension of the tip link using so-called adaptation motors 


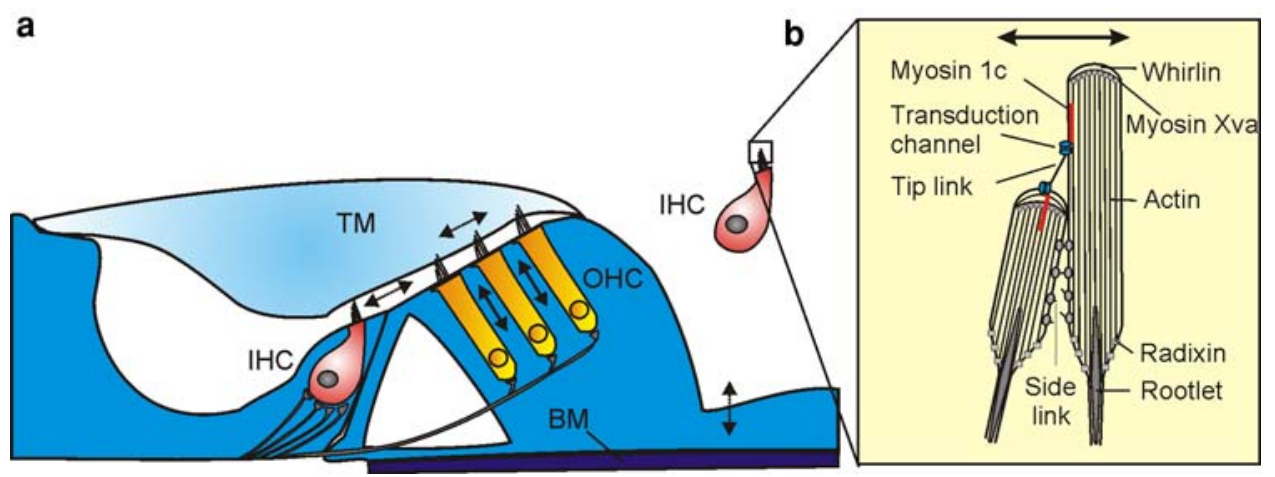

Fig. 2 Hair cells in the organ of Corti. a Schematical cross-section of the organ of Corti with the tectorial membrane (TM) covering the stereocilia of sensory inner hair cells (IHC) and electromotile outer hair cells (OHC). Sound induces local vibrations of the basilar membrane (BM) and a lateral displacement of hair-cell stereocilia (arrows). b Enlarged view of the stereocilia of an inner hair cell. The transduction channels of the longer stereocilium are dynamically anchored to actin filaments through myosin 1c. A tip-link filament pulls the transduction channels open when the stereocilia move in the plane indicated by the arrow

The primary transduction process in hair cells requires a complex dynamic environment to function properly. To generate neuronal signals upon detecting a very faint sound (the detection threshold in humans is $\sim 10^{-16} \mathrm{~W} / \mathrm{cm}^{2}$ ), and to discriminate frequencies over a range of three orders of magnitude $(20-20 \mathrm{kHz})$, the Corti organ must amplify the primary signal. Research in cochlear amplification has seen exciting advances in recent years. I will only briefly outline this topic here, as it is more an auxiliary than a primary process. Amplification of the primary signal, which are local vibrations of the Corti organ due to resonance, is performed by the outer hair cells (OHCs) of the Corti organ (reviews: Fettiplace and Hackney 2006; Frolenkov 2006; Ren and Gillespie 2007; Ashmore 2008). OHCs possess the unususal (perhaps unique) property of electromotility. They contract upon depolarization, and they elongate upon hyperpolarization. This motorresponse to changes in membrane voltage is extremely rapid. An $\mathrm{OHC}$ can go through tens of thousands of contraction/elongation cycles per second and can thus follow the vibration frequency caused by resonance at any particular spot along the cochlear. Importantly, the stereocilia of OHCs are embedded in the tectorial membrane (Fig. 2a) and, thus, constitute a mechanical link between the sensory epithelium and the tectorial membrane. As the OHCs oscillate, they "shake" the entire structure at the point of resonance and amplify the local movement of endolymph that stimulates the sensory IHCs. In mammals, electromotility is mediated by the protein prestin, a membrane protein that changes its volume under the control of the membrane voltage (Zheng et al. 2000; Dallos et al. 2006, 2008). The protein swells by voltagedependent uptake of chloride ions, a process that is extremely fast. Electromotility is thus the orders of magnitude faster than any motion based on cAMP-consuming motor proteins. The OHCs amplify the primary signal by a factor of 100-1,000 and hence allow the IHCs to operate at 
the levels of sound pressure that constitute our normal auditory environment.

\section{Phototransduction: dynamic scaffolds}

Since more than five decades, a constant stream of excellent papers has been published on signal transduction in photoreceptors of vertebrates and invertebrates. Today, phototransduction is arguable to be the best understood of all sensory transduction cascades, and a number of excellent reviews describe the most recent advances (Burns and Arshavsky 2005; Fu and Yau 2007; Lamb and Pugh 2004, 2006; Okawa and Sampath 2007; Wang and Montell 2007; Luo et al. 2008). In this chapter, I will concentrate on one particular aspect of phototransduction: the spatial organization of the transduction cascade and the temporal redistribution of transduction components. Research on this topic is critical to the understanding of primary processes in all sensory cells, and the advances in organellar proteomics is expected to promote this field considerably (Yates et al. 2005; Andersen and Mann 2006; Au et al. 2007). Proteomic studies provide a specific protein inventory of a sensory organelle which can be used to examine proteinprotein interactions and their significance for sensory transduction (Liu et al. 2007). Drosophila photoreceptors were the first sensory cells where such interactions were shown to exist on a large scale. In the compound eye, the microvilli of the rhabdomere contain the scaffold protein INAD (for the terminology of Drosophila photoreceptor gene products see Wang and Montell 2007). INAD contains five PDZ domains (Huber 2001; Jemth and Gianni 2007) which serve as interfaces for the interaction with multiple proteins of the signal transduction cascade. INAD polymers constitute a scaffold which binds together the transduction proteins in a supramolecular complex, termed a signalplex
(Li and Montell 2000). Within the signalplex, diffusion distances are short and transduction is fast (Fig. 3). Upon illumination, the absorption of a photon converts rhodopsin to metarhodopsin which activates phospholipase $C \beta$ via the $\mathrm{G} \alpha_{\mathrm{q}}$ subunit of a GTP-binding protein. The resulting release of diacylglycerol (DAG) opens the transduction channels TRP and TRPL which depolarize the photoreceptor through cation $\left(\mathrm{Na}^{+}, \mathrm{Ca}^{2+}\right)$ influx (Montell 2005). The active second messenger for TRP and TRPL appears to be DAG itself or one of its metabolites, most likely a polyunsaturated fatty acid (Chyb et al. 1999; Leung et al. 2008). The $\mathrm{Ca}^{2+}$ signal induced by the TRP/TRPL channels plays a pivotal role in the termination of the light response. $\mathrm{A} \mathrm{Ca}^{2+}$-dependent protein kinase $\mathrm{C}$ phosphorylates TRP channels as well as myosin III (NINAC; Li et al. 1998), and both processes contribute to response termination. In fact, fast signal termination depends on the interaction of PKC with the INAD scaffold (Wes et al. 1999), and this currently represents the only proven effect of protein coordination on transduction kinetics in this cell. It is still an open question to what extent the signalplex contributes to the extremely rapid light response in flies, the fastest G-protein mediated process known. An exciting development in this field is the finding that the INAD scaffold is not a fixed structure but that its interactions with other proteins can be regulated by light. Using X-ray crystallography, Mishra et al. (2007) found that the fifth PDZ domain of INAD can exist in two different forms. In one form the domain binds other proteins. In the other form an intramolecular disulfide bond prevents binding. Interestingly, PDZ5 toggles between the two conformations under the influence of light in such a way that illumination can switch off protein binding to PDZ5. This light effect on scaffolding appears to improve the temporal resolution of vision in flies and indicates a new approach to studying the photoreceptor signalplex. Dynamic effects on protein coordination may be important
Fig. 3 The signalplex of fly photoreceptors. Schematical view of primary processes in a microvillus from a fly rhabdomer. A polymer of INAD scaffold proteins coordinates the transduction proteins rhodopsin, $\mathrm{G} \alpha_{\mathrm{q}}$, phospholipase C (PLC), protein kinase $\mathrm{C}$ (PKC), transient receptor potential channel (TRP), and TRP-like channel (TRPL). Illumination leads to release of inositol-1,4,5-trisphosphate $\left(\mathrm{IP}_{3}\right)$, diacylglycerol (DAG), and polyunsaturated fatty acids (PUFA), which open the TRP/TRPL channels

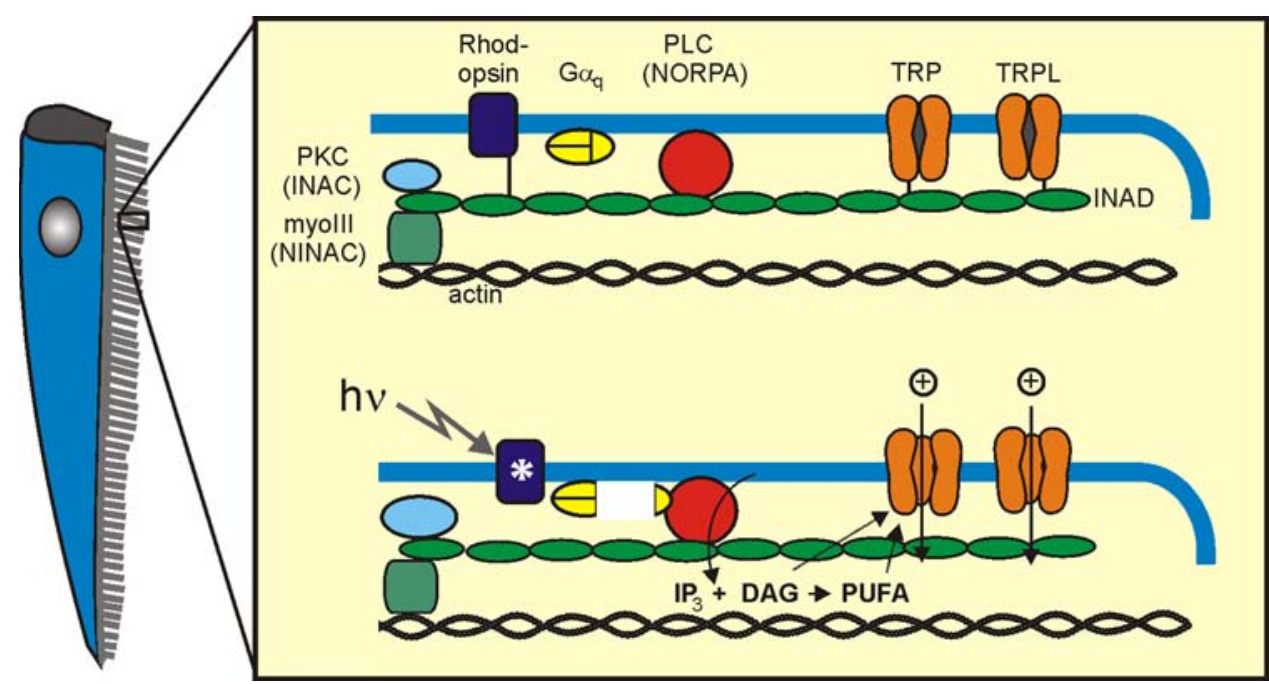


for the function of the phototransduction system (Hardie 2007; Montell 2007; Sanxaridis et al. 2007).

In vertebrate photoreceptors, studies of supramolecular transduction complexes were mainly focussed on the rim regions of the outer segment where the edges of the discs are in close proximity $(<10 \mathrm{~nm})$ to the plasma membrane (Fig. 4). In this rim region, the role of scaffold protein is thought to be played by the protein GARP (glutamic acid-rich protein). Having itself no intrinsic structure (Batra-Safferling et al. 2006), GARP binds to a number of phototransduction proteins and helps to assemble them into a molecular complex (Körschen et al. 1999). Interestingly, GARP comes both in soluble form (GARP1, GARP 2) and as a membrane-bound appendage to the photoreceptor transduction channel, the cGMP-gated channel in the plasma membrane. As such, it can function as a molecular glue between the metabotropic transduction in the disc membrane, and the effector proteins in the plasma membrane that generate light-dependent electrical and $\mathrm{Ca}^{2+}$ signals. Indeed, in vitro binding experiments have shown that GARP coordinates phosphodiesterase, guanylyl cyclase, the retinal ATP-binding cassette transporter, and peripherin 2 on the disc side with the cGMP-gated channel, and the $\mathrm{Na}^{+} / \mathrm{Ca}^{2+}-\mathrm{K}^{+}$exchanger on the side of the plasma membrane (Körschen et al. 1999; Poetsch et al. 2001; Molday 2007). It is not yet known whether this spatial organization serves structural or functional purposes-or both. But it points to the notion that the rim region of vertebrate photoreceptors shows a similarly high degree of molecular coordination as the signalplex in Drosophila photoreceptors. The speed and efficiency of sensory signal generation and termination may require such spatial order and may comprise more, as yet unidentified proteins. A recent addition to the molecular complex in the rim region is a retinal ryanodine receptor, related to the large $\mathrm{Ca}^{2+}$ channel protein known to mediate electromechanic coupling in skeletal muscle (Shoshan-Barmatz et al. 2007). This protein is located at the edge of the disc and may contribute to the regulation of $\mathrm{Ca}^{2+}$ signals within the microdomain of the rim region. $\mathrm{Ca}^{2+}$ signals drive recovery and adaptation in photoreceptors (Fain et al. 2001) and the retinal ryanodin receptor may be involved in this process.

Reversible attachment to a transduction scaffold may constitute an effective mechanism for sensory adaptation. Proteins may be tethered to the signalplex for high sensitivity and may be removed from the complex to reduce sensitivity. This concept arises from the observations of lightinduced protein translocation in photoreceptors (Calvert et al. 2006). In both Drosophila and in mouse rod photoreceptors, key members of the phototransduction cascade are shuttled to and from the transduction site in a light-dependent way. The heterotrimeric GTP-binding protein transducin in vertebrates sticks to the disc membrane in the dark by a farnesyl group on its $\gamma$ subunit and an acyl group on its $\alpha$ subunit. This double-anchor effectively attaches the inactive trimer to the discs. During photoactivation of rhodopsin, however, transducin dissociates into the $\beta \gamma$ dimer and the active $\mathrm{G} \alpha$-GTP, both of which have increased solubility because each has only one membrane anchor. This "photosolubilization" of transducin releases much of the protein from the disc during intense or prolonged illumination. The soluble protein is able to diffuse to the inner segment where it is sequestered by a still unknown mechanism (Sokolov et al. 2002; Lobanova et al. 2007), until it returns again to the outer segment in the dark. A similar translocation of $\mathrm{G} \alpha_{\mathrm{q}}$ is thought to contribute to light-adaptation in the fly photoreceptor (Kosloff et al. 2003). In both cells, G proteins and arrestin - a key protein for response termination-were

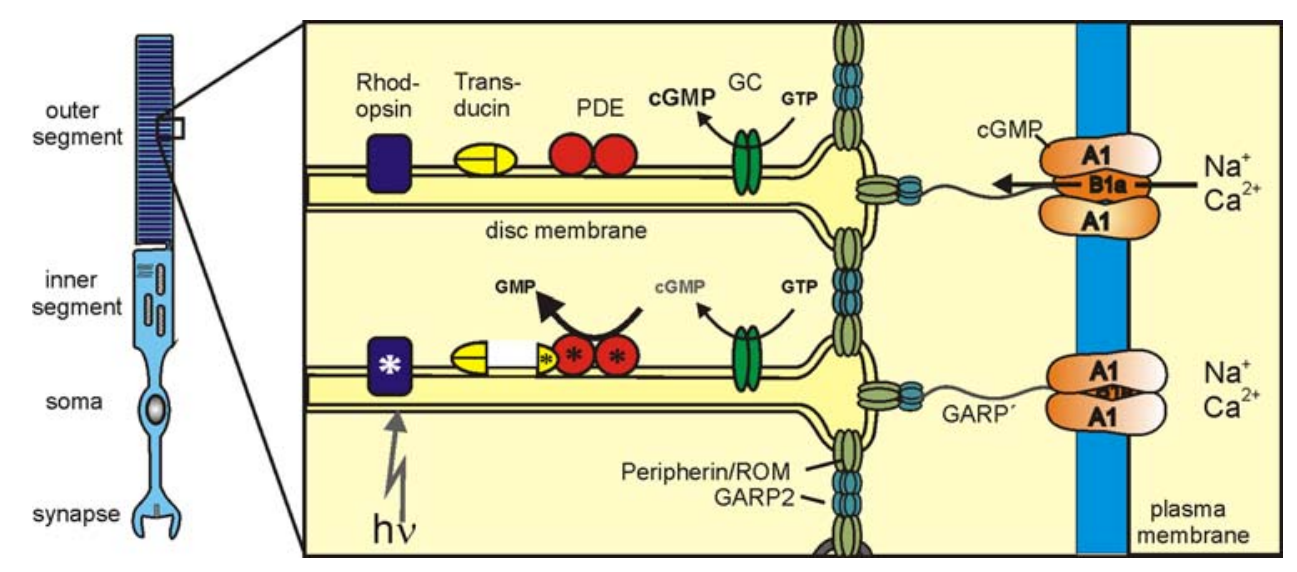

Fig. 4 The rim region of the vertebrate photoreceptor outer segment. cGMP-gated transduction channels in the plasma membrane (with their subunits CNGA1 and CNGB1a) are connected to the intracellular disc membrane via a GARP' domain (GARP, glutamic acid-rich protein) which forms the C-terminus of each CNGB1a subunit. Soluble
GARP and peripherin connect discs and transduction channels in the rim region. $c G M P$ cyclic guanosine monophosphate, $G C$ guanylyl cyclase, GTP guanosine triphosphate, $P D E$ phosphodiesterase, $R O M$ rod outer segment membrane protein. Illumination leads to a decline of the cGMP concentration and closure of cGMP-gated cation channels 
shown to travel in opposite directions (Lee and Montell 2004; Strissel et al. 2006). Attenuation of the light response is brought about by sequestration of transducin in the inner segment and accumulation of arrestin in the outer segment (Calvert et al. 2006). Such translocation of proteins between the signaling complex and a non-photosensitive compartment is not restricted to soluble proteins. The TRPL channel of fly photoreceptor undergoes a lightdependent, reversible translocation between rhabdomers and cell body (Bähner et al. 2002; Meyer et al. 2006), a process that may involve endocytosis and intracellular transport by motor proteins. Whatever the exact molecular mechanisms of protein translocation are, the data available today clearly show that signaling complexes in photoreceptors can be subject to light-dependent restructuring. Such dynamic regulation of protein networks may have profound effects on transduction efficiency-not only in vision. Once again, the photoreceptor may serve as a model cell for the exploration of new principles in sensory transduction.

\section{Taste transduction: gustatory genetics}

Taste transduction research has rapidly advanced in recent years through genetic examination of the taste system (Chandrashekar et al. 2006; Huang et al. 2006; Roper 2007). In mammals, two families of metabotropic taste receptors, T1R and T2R (gene symbols Tas $1 r$ and Tas $2 r$ ) are expressed in the chemosensory microvilli at the apical pole of taste receptor cells. T1R-expressing cells probe food for attractive stimuli (sweet and umami), while T2R cells mediate the aversive bitter taste. Sweet taste can be elicited by a range of mono- and polysaccharides but also by various amino acids, peptides and proteins as well as by artificial sweeteners and by certain salts (Roper 2007). The umami taste quality is caused by the detection of certain L-amino acids, most distinctly by sodium glutamate which generates a pleasant meaty taste. The T1R protein family mediates sweet and umami detection by differential combination of its three members, T1R1, T1R2, and T1R3 (Fig. 5). Dimers of T1R2 and T1R3 (and possibly T1R3 homodimers) operate as sweet sensors, while T1R1/T1R3 dimers are umami-selective (Zhao et al. 2003; Damak et al. 2003). The receptors for bitter stimuli, the T2R family, are activated by various toxic and non-toxic substances mainly present in plants. It is generally believed that bitter taste serves to detect harmful substances and to prevent the animal from swallowing noxious material. T2R receptors differ from the T1R family in that they have short $\mathrm{N}$-termini and do not form dimers (Fig. 5). They are coded by a gene family of 36 functional genes in mice and 25 genes in humans. Importantly, each bitter cell expresses multiple T2Rs and is, therefore, responsive to a wide range of bitter substances (Adler et al. 2000; Mueller et al. 2005; Behrens and Meyerhof 2006; Behrens et al. 2007). Both T1Rs and T2Rs couple the initial taste signal to activation of a phospholipase C (PLC $\beta 2$; Zhang et al. 2003). This process is mediated by the GTP-binding protein gustducin (McLaughlin et al. 1992) and leads to the release of $\mathrm{IP}_{3}$ and $\mathrm{Ca}^{2+}$. The common transduction channel of this pathway is TRPM5, a cation channel gated by $\mathrm{Ca}^{2+}$ (Perez et al. 2002; Zhang et al. 2003, 2007). While the prominent role of the T1Rs and T2Rs in taste transduction, together with its transduction cascade that targets TRPM5, is now firmly established,
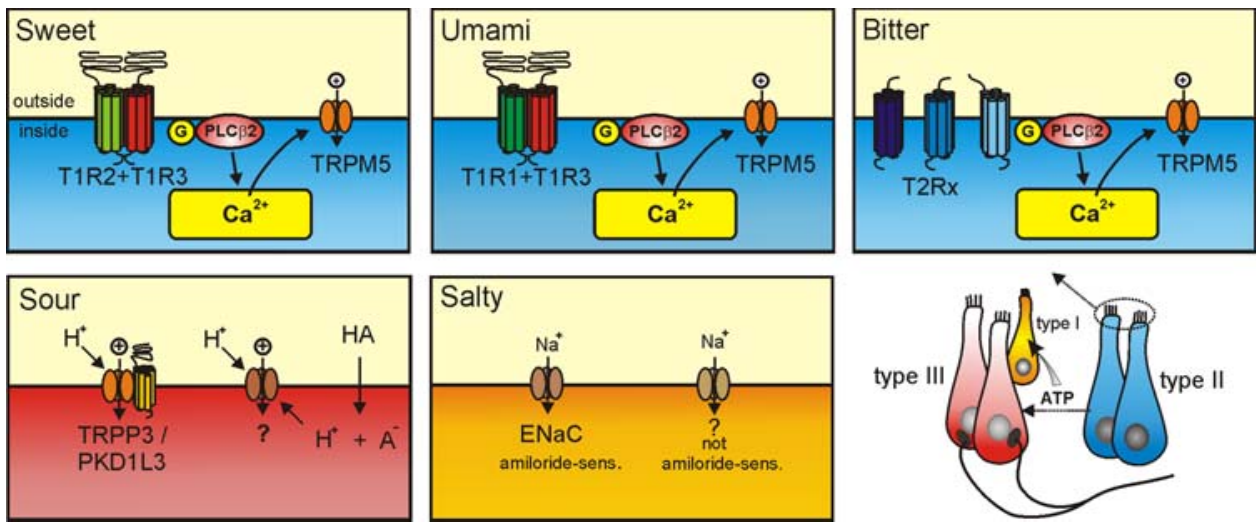

Fig. 5 Primary processes in taste cells. Transduction models for the chemosensory membrane of taste cells. The metabotropic receptor families T1R and T2R mediate sensitivity to sweet, umami, and bitter by activating phospholipase $\beta 2$ (PLC $\beta 2$ ) through a GTP-binding protein $(\mathrm{G})$. The resulting release of $\mathrm{Ca}^{2+}$ from intracellular stores opens transient receptor potential M5 channels (TRPM5) which generate a depolarizing receptor potential. Sour taste is mediated by a combination of transient receptor potential P3 channels (TRPP3) and polycystic- kidney-desease-like ion channels (PKD1L3). Additional $\mathrm{pH}$ effects on other ion channels, as well as proton uptake into taste cells have also been reported. Salt taste may, in part, be mediated by $\mathrm{Na}^{+}$-permeable epithelial sodium channels (ENaC). Sweet, umami, and bitter taste resides in type II cells (blue) which release ATP as paracrine transmitter. Sour taste is located in the presynaptic type III cells ( red), and salt taste is mediated by type I cells (yellow) which also remove ATP from the taste bud (colors refer to online version of this article) 
evidence obtained in behavioral assays points to additional processes involved in sweet and umami transduction. Residual sweet and umami responses were found with mice after genetic ablation of either T1R3 receptors (Damak et al. 2003; Delay et al. 2006; Maruyama et al. 2006), gustducin (Danilova et al. 2006), or TRPM5 (Damak et al. 2006), suggesting that a TRPM5-independent, yet unidentified transduction pathway exists in taste cell. Also, there appears to be cross-talk between sweet and bitter taste, which may result from direct effects of bitter compounds on the TRPM5 channel (Talavera et al. 2008). Finally, substantial species differences can be expected in taste transduction as different animals need different food (Ma et al. 2007). Carnivorous Felidae, for example, (cats, tigers, cheetahs) were shown to have a Tas $1 r 2$ pseudogene, so that the T1R2 protein is not expressed and the T1R2/T1R3 dimer cannot be formed ( $\mathrm{Li}$ et al. 2005). This may explain the cats' indifference to sweet stimuli and reflect the lack of selective pressure on the maintenance of sweet taste in the evolution of these animals.

The search for transduction mechanisms of sour-sensitive taste cells has been hampered by the fact that the adequate stimulus, protons, affects virtually every protein with amino acid residues that can bind $\mathrm{H}^{+}$. Thus, $\mathrm{pH}$ effects can be measured with most channels, transporters and proteins involved in signal transduction, and it is difficult to prove that a $\mathrm{pH}$ effect on an individual protein is related to the physiological proton sensor of a sour-selective taste cell. This conundrum is made worse by the fact that protons can reach the basolateral membrane of taste cells through the paracellular pathway, and that protonated acids can cross the plasma membrane and cause intracellular acidification. The actions of $\mathrm{pH}$ changes are, therefore, essentially unspecific and not localized. Physiological data, however, show that there is a subpopulation of taste cells equipped with specific $\mathrm{pH}$ sensitivity. Such a property could arise from specific expression of proton-gated ion channels and/or by a reduced cytosolic $\mathrm{pH}$ buffer capacity. Indeed, intracellular acidification and stimulus-related $\mathrm{Ca}^{2+}$ signals could be demonstrated in a subpopulation of taste cells upon extracellular $\mathrm{pH}$ changes (Richter et al. 2003). The most convincing set of evidence for a specific $\mathrm{H}^{+}$sensor in sour-specific taste cells comes from studies of an ion channel from the TRP family, TRPP3 (synonyms: TRPP3 = PKD2L1; TRPP = polycystin family; Delmas 2005). This protein is expressed in a subset of taste cells that are not sensitive to other taste qualities and, in conjunction with the related protein PKD1L3, confers acid sensitivity when expressed in the cell line HEK 293 (LopezJimenez et al. 2006; Ishimaru et al. 2006; Inada et al. 2008). When TRPP3-expressing taste cells are removed by genetic manipulation, animals do no longer respond to sour stimuli, while the other taste qualities are intact (Huang et al. 2006).
While many details of the sour transduction process are not yet clear, these data strongly suggest that TRPP3 is part of the sour taste receptor (Meyerhof 2008).

Salt detection is thought to work through cation ion channels which conduct $\mathrm{Na}^{+}$or $\mathrm{K}^{+}$from the surface of the tongue into salt-sensitive cells. In parallel, $\mathrm{Cl}^{-}$ions are thought to take the paracellular route across the taste epithelium (Roper 2007). A candidate for $\mathrm{Na}^{+}$taste is the amiloride-sensitive epithelial $\mathrm{Na}^{+}$channel $\mathrm{ENaC}$ whose three subunits $\alpha, \beta$. and $\gamma$ are expressed in some taste receptor cells (Lin et al. 1999). Both amiloride-sensitive and amiloride-insensitive components of salt taste were identified by electrophysiology and in the behavioral experiments (Avenet and Lindemann 1991; Shigemura et al. 2008). Amiloride-sensitive, highly $\mathrm{Na}^{+}$-selective channels are present in some taste cells (Sugita 2006). However, the definite answer to the question whether $\mathrm{ENaC}$ mediates salt taste must probably await the generation of a taste-cell specific conditional knockout mouse, as global deletions of any of the three $\mathrm{ENaC}$ subunits results in perinatal lethality (Hummler and Vallon 2005). Thus, the transduction mechanism of salt taste is presently not well understood.

An important point for the examination of primary processes in taste transduction is to identify the right cell types within a taste bud. Evidence from a number of morphological and physiological studies supports the view that only a subset of cells in the taste bud expresses taste receptors and transduction proteins. Other cells have different functions including synaptic transmission or glia-like supportive function (Roper 2007). At present the data provide a scenario in which taste receptor cells (type II cells; Fig. 5) respond to tastants with the release of ATP, probably through pannexin 1 hemichannels (Finger et al. 2005; Huang et al. 2007). ATP appears to act as paracrine transmitter on type III cells which express $\mathrm{P} 2 \mathrm{X}_{2}$ and $\mathrm{P} 2 \mathrm{X}_{3}$ purinergic receptors and form synapses with afferent neurons (Finger et al. 2005). Finally, type I cells may limit widespread diffusion of ATP by an ecto-ATPase (Bartel et al. 2006), thus serving a glia-like function in the taste bud. This working hypothesis of a paracrine transmission system illustrates the complexity of signaling inside a taste bud. Many observations have yet to be integrated into this model. For example, amiloride-sensitive currents are restricted to type I cells (Vandenbeuch et al. 2008) suggesting that these glia-like cells are also responsible for salt taste. Sour taste, in contrast, was localized to the type III cells of the taste bud (Huang et al. 2008; Kataoka et al. 2008). Substantial differences in morphology and expression patterns have been demonstrated between taste buds of rats and mice (Ma et al. 2007) and between different taste buds on the same tongue (Kinnamon et al. 1993; Romanov and Kolesnikov 2006). Moreover, psychophysical effects of peripheral neuromodulators (Heath et al. 2006) have to be 
examined as they may regulate sensory signal processing in the taste bud.

\section{Olfactory transduction: coping with fuzzy receptors}

The olfactory system of vertebrates is designed to detect an unlimited number of odorants (Ache and Young 2005). To do this, the system exposes a set of roughly 400 (humans) to 1,000 (dogs, rodents) olfactory receptor proteins to the air inside the nasal cavity. The receptors are encoded by a large family of intron-less genes (Buck and Axel 1991), scattered all over the genome (Fig. 6), and are expressed in olfactory receptor neurons (ORNs). The receptor proteins not only determine to which compounds the ORN will respond but also help to target the ORN axon to its appropriate connection point in the brain. Consequently, all axons of a ORN population that expresses the same receptor converge onto the same projection neurons in the olfactory bulb (Mombaerts 2006). Most authors favor the notion that only a single olfactory receptor gene is expressed in each individual ORN (Malnic et al. 1999; Mombaerts 2004). Intense research efforts are currently focussed on the question how a single receptor gene is chosen from the large receptor gene repertoire of the olfactory system. Only one allele of each olfactory receptor is transcribed in a mature ORN (Chess et al. 1994; Ishii et al. 2004), and the selected gene product appears to suppress the transcription of all other olfactory receptor genes (Serizawa et al. 2003, 2004). Various minigenes, enhancer elements and homeodomain transcription factors have been shown to promote expression of receptor genes within a gene cluster, and they

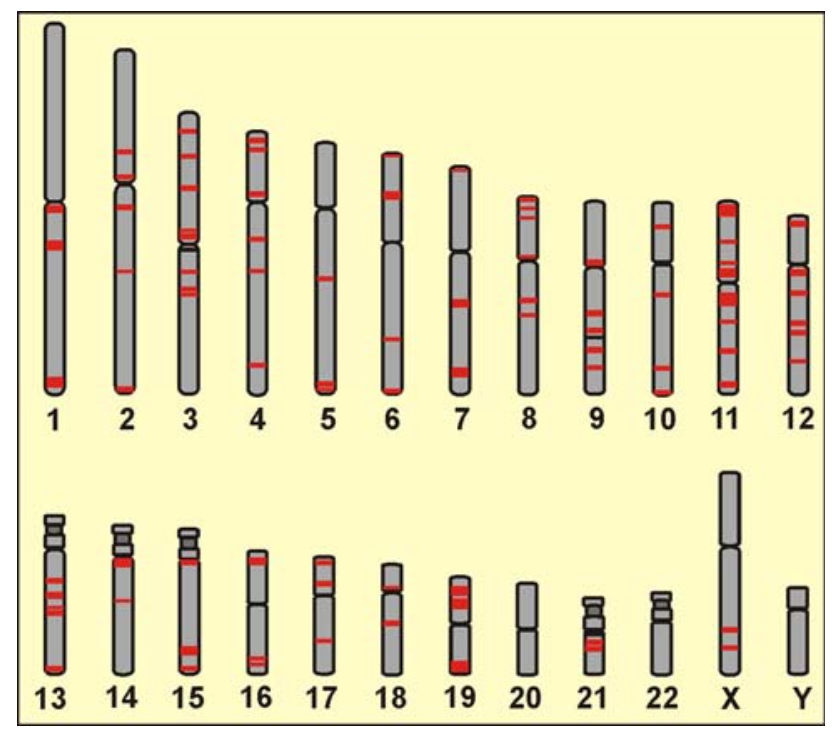

Fig. 6 Odorant-receptor genes on human chromosomes. The bands indicate gene clusters that contain groups of odorant-receptor genes. Such clusters are present on almost all chromosomes seem to play key roles in controlling the expression program (Rothman et al. 2005; Hirota et al. 2007; Fuss et al. 2007). Importantly, an ORN tolerates the simultaneous expression of two different olfactory receptors only if one of them is coded by a pseudogene and is, hence, not functional (Lomvardas et al. 2006). Transcription of the first receptor gene apparently exerts an effective feedback repression upon all other receptor genes. Alternatively, expression of multiple receptors may prevent the ORN from developing into a mature sensory cell. Despite remarkable progress in recent years, the precise genetic basis of the one cell-one receptor phenomenon is not fully understood.

Although the family of olfactory receptor genes is large, 1,000 receptors appear to be a small repertoire of sensors compared to the multitude of possible odorants to which a limiting number cannot be rationally assigned. This means that each receptor type must be able to bind a large number of different odorants. In other words, the olfactory receptors must work with relatively low odorant selectivity. This was first demonstrated by single unit recordings from ORNs, challenged with a diverse panel of odorants (Sicard and Holley 1984). Even in experiments with only 20 test odorants, most ORNs responded to more than ten, illustrating that the activity of a single ORN, or a single ORN population expressing the same odorant receptor, does not provide the brain with conclusive information on odor identity. In fact, this information is extracted from the spatial and temporal activity pattern of all ORNs (Friedrich 2006; Spors et al. 2006; Wachowiak and Shipley 2006; Wesson et al. 2008). Such pattern analysis does not require highly selective sensors. It operates efficiently with a set of broadly tuned sensors which, collectively, produce unique signal patterns for each stimulus. In the olfactory system, the set of 400-1,000 low-selectivity receptors accommodates an unlimited range of stimuli and still generates unique neuronal activity patterns for each of them. However, working with low-selectivity receptors brings fundamental problems for the task of signal transduction. Most odorants bind to the receptors with low affinity and activate the receptors only briefly. Bhandawat et al. (2005) estimated the mean dwell time of an odorant bound to its receptor to be less than $1 \mathrm{~m} \mathrm{~s}$. Such a brief contact is hardly sufficient to trigger the transduction cascade by activating the G-Protein $\mathrm{G}_{\mathrm{olf}}$ (Fig. 7). Accordingly, the synthesis of the second messenger cAMP by adenylyl cyclase type III (AC III, Fig. 7) proceeds at a low rate. Measurements from amphibian ORNs showed that the maximal rate of cAMP synthesis in an ORN is about 200,000 cAMP molecules per second (Takeuchi and Kurahashi 2005). This maximal rate is similar to the number of cGMP molecules hydrolyzed upon absorption of a single photon in a rod photoreceptor (250,000 molecules per photon; Stryer 1986). 


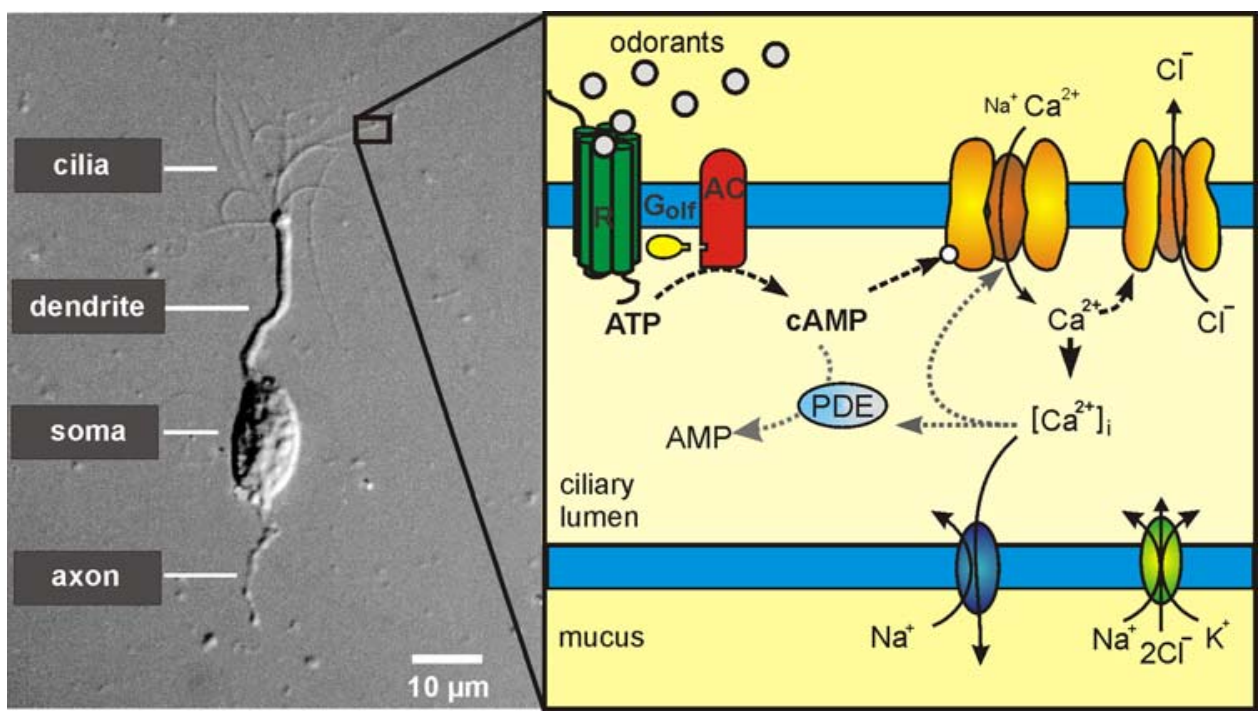

Fig. 7 Primary processes in olfactory sensory cilia. Left: micrograph of an isolated olfactory receptor cell showing the chemosensory cilia at the ending of the neuron's dendrite (from: Kleene and Gesteland, 1981). Right current transduction model. AC adenylyl cyclase type III, $A T P$ adenosine triphosphate, $\left[\mathrm{Ca}^{2+}\right]_{i}$ intracellular calcium concentra-

Thus, in contrast to phototransduction, the metabotropic transduction step on olfactory transduction operates with low efficiency. This point is supported by the consistent observation that odorant concentrations used for physiological experimentation with ORNs have to be in the range of $1-100 \mu \mathrm{M}$ to detect cAMP synthesis or to record cAMPdependent receptor currents (Pace et al. 1985; Firestein et al. 1993; Araneda et al. 2000). In fact, metabotropic transduction in ORNs appears to work without any molar amplification: Micromolar concentrations of odorants are needed to generate micromolar concentrations of cAMP in ORNs. The absence of effective metabotropic amplification results directly from the use of low-selectivity receptors which, in turn, is required for a system open to an unlimited range of odorants. How then, can the olfactory system work as the highly sensitive detection system with amazing powers of odor discrimination?

Odorants can be detected at extremely low concentrations, much lower than the $1-100 \mu \mathrm{M}$ used in physiological experiments on isolated cells. It is difficult to compare results obtained from single ORNs with the performance of the olfactory system in vivo for at least three reasons: (1) ORNs show an extremely high degree of convergence, as roughly 2,000 ORNs are connected with a single mitral cell in the olfactory bulb. It is conceivable that such a large ensemble of afferent neurons causes excitation in a mitral cell even if each individual ORN is only slightly activated. Thus, temporal summation of multiple weak signals may contribute to olfactory sensitivity. (2) The sensory membrane of ORNs is embedded in a mucus layer that, in tion, $c A M P$ cyclic adenosine monophosphate, $G_{\text {olf }}$ olfactory GTP-binding protein, $P D E$ phosphodiesterase. The two transduction channels, cAMP-gated cation channels and $\mathrm{Ca}^{2+}$-gated chloride channels, are indicated in the upper membrane. The ion transporters that extrude $\mathrm{Ca}^{2+}$ and accumulate $\mathrm{Cl}^{-}$are depicted at the bottom membrane of the cilium terrestrial animals, contains high concentrations of odorantbinding proteins (Pelosi 2001; Pelosi et al. 2006; Ko and Park 2008; Laughlin et al. 2008). These small, soluble proteins belong to the lipocalin-family, proteins that can shuttle hydrophobic molecules through body fluids and across cell membranes. In the olfactory mucus, these binding proteins display odor-specificity (Löbel et al. 2002) and can interact with odorant receptor proteins (Matarazzo et al. 2002). The precise role of these proteins in olfaction is not understood, but they are expected to influence the interaction between odorants and their receptors. (3) ORNs possess an unusual signal amplification mechanism that boosts the odor-induced depolarization and may be critical for responses to weak stimuli. This mechanism utilizes the $\mathrm{Ca}^{2+}$ influx through cAMP-gated transduction channels in the chemosensory membrane (Fig. 7). $\mathrm{Ca}^{2+}$ opens chloride channels which conduct a depolarizing efflux of chloride ions (Kleene and Gesteland 1991). The anion influx strongly amplifies the receptor potential and depolarizes the ORNs sufficiently for excitation (Kurahashi and Yau 1993; Lowe and Gold 1993; Kleene 1997). To support this excitatory chloride current, ORNs accumulate chloride and support an elevated intracellular chloride concentration (Reuter et al. 1998; Kaneko et al. 2004). Current research efforts in this field focus on the molecular identification of the calciumdependent chloride channels (Reisert et al. 2003; Kaneko et al. 2006; Pifferi et al. 2006; Caputo et al. 2008; Schroeder et al. 2008; Yang et al. 2008) and on the mechanisms of chloride homeostasis that support this signal amplification (Reisert et al. 2005; Nickell et al. 2007; Smith et al. 2008). 
While ORNs have to operate with low selectivity, pheromone receptors in the vomeronasal organ display a high degree of specificity and sensitivity for the chemical compounds that orchestrate reproductive behavior among the members of a species. Consequently, the primary processes are fundamentally different between these two sensory modalities. The prototypical pheromone receptors of the silk moth Bombyx mori basically respond to single pheromone-binding events, although the exact nature of this process and, in particular, the role of pheromone-binding proteins is still not fully understood (Kaissling 2001). But mammalian pheromone detectors are highly sensitive as well. Studies of pheromone receptors in the mouse vomeronasal organ (VNO) revealed detection thresholds near $10^{-11} \mathrm{M}$ for the neuronal response (Leinders-Zufall et al. 2000). VNO neurons employ two distinct sets of pheromone receptors, the V1R and V2R families, each of which comprises 100-200 different receptors (Dulac and Wagner 2006; Zufall and Leinders-Zufall 2007; Dulac and Kimchi 2008). The V1R family recognizes small urinary molecules that act as pheromones in mammals. Each V1R neuron seems to express only a single member of the V1R receptor family and, consequently, displays high pheromone specificity. A separate population of VNO neurons expresses V2R genes. These cells respond to urinary peptides, in particular to major histocompatibility complex (MHC) class 1 peptides (Leinders-Zufall et al. 2004) and help conspecific animals to gain information related to the immune system of their mates. The transduction cascade used by both V1R and V2R neurons is also different from that operating in ORNs. Phospholipase $\mathrm{C}$ is believed to be the target enzyme, releasing $\mathrm{IP}_{3}, \mathrm{Ca}^{2+}$, DAG and polyunsaturated fatty acids (PUFA) as second messengers upon pheromone stimulation (Liman and Zufall 2004). Robust evidence is available for a central role of the protein TRPC2 as transduction channel (Zufall et al. 2005). TRPC2 is expressed in the chemosensory microvilli of VNO neurons (Liman 1999), the channel is gated by DAG (Lucas et al. 2003), and TRPC2 knock-out mice lose the ability to distinguish between male and female conspecifics (Stowers et al. 2002; Leypold et al. 2002; Kimchi et al. 2007). Nevertheless, some aspects of pheromone-driven behavior remain intact in the TRPC $2^{-/-}$mice, in particular the detection of MHC 1 peptides (Kelliher et al. 2006). This finding suggests that a different population of VNO neurons exists which does not use TRPC2 as transduction channel.

Intense examination of the VNO and the olfactory epithelium currently challenges the traditional view that the two systems are dedicated exclusively to two discrete functions, namely pheromone control and olfaction (Spehr et al. 2006). It becomes clear that both systems contain various different populations of neurons, each with a specific purpose and specific molecular equipment. The characteriza- tion of these chemosensory cells and their sensory function is an exciting task for sensory physiologists (Elsaesser et al. 2005; Liberles and Buck 2006; Leinders-Zufall et al. 2007).

\section{Evaluating electromagnetic fields: more primary processes}

In addition to analyzing the intensity and wavelength of visible light, animals can extract vital information from the degree of light polarization, from infrared radiation, as well as from electrical fields and from the Earth's magnetic field. Exciting recent developments have yielded insights into some amazing primary processes that mediate these tasks. I will briefly review progress in polarization vision and magnetoreception. For the topics of electroreception and infrared perception, I refer the reader to a set of excellent reviews recently published in this journal (Bleckmann et al. 2004; von der Emde 2006; Caputi and Budelli 2006).

Many animals are able to detect light polarization and to obtain complex information through this sensory channel. Non-polarized sunlight reaches the Earth and is polarized when it is scattered or reflected by all kinds of materials within the atmosphere, on the terrestrial surface, or in water. The atmosphere creates a stereotypical pattern of celestial light polarization which can be used for navigational purposes (Wehner 2001; Homberg 2004; Horváth and Varjú 2004; Pfeiffer and Homberg 2007; Krapp 2007). Moreover, reflective surfaces like water or glass, as well as scales, elythrae and other shiny animal surface structures, polarize light, an effect that can be used to search water, identify prey, and break other animals' camouflage (Kriska et al. 1998; Shashar et al. 2000). The primary transduction process of polarization vision is based on the photoreceptors with pronounced absorption anisotropy (dichroism). Such photoreceptors show a preferred response of their photosensitive organelles to polarized light with a certain electric vector (e-vector). The rhabdomeric photoreceptors of insects and cephalopods harbor their rhodopsin in microvilli, membrane tubes of $\sim 50 \mathrm{~nm}$ diameter. Apparently, the rotational freedom of rhodopsin is limited in the microvillar membrane, such that the orientation of the retinal molecules is mainly parallel to the long axis of the microvillus. Polarized light is, therefore, best absorbed when its e-vector is aligned along the microvilli. Furthermore, all microvilli in a polarization-sensitive photoreceptor are aligned in parallel (Wehner and Bernard 1993; Meyer and Domanico 1999) so that the entire rhabdomer displays the same dichroism as each of its microvilli. In contrast to the rhabdomeric photoreceptors, the ciliary photoreceptors of vertebrates seem not to be very useful for polarization vision. It is generally held that rhodopsin molecules rotate freely within the disc membranes without any preferred orientation. Light traveling 
axially through the outer segment thus hits retinal molecules that point into all possible orientations of the membrane plane, and no dichroism can occur. While most terrestrial vertebrates are polarization-blind, many fish species have been shown to be polarization-sensitive. Anchovies have tilted the discs in their cone photoreceptors by $\sim 90^{\circ}$ so that the incident light enters each disc from the side (Heß et al. 2006) and, presumably, hits retinal molecules that are more or less aligned with the disc membranes and preferably absorb light polarized in the membrane plane. This appears to be a solution to generate dichroic ciliary photoreceptors, but other strategies may also exist (Roberts and Needham 2007; Ramsden et al. 2008). A new aspect of polarization vision is the recent discovery that marine mantis shrimps (stomatopod crustaceans; Marshall et al. 2007) are able to detect circularly polarized light, and even to distinguish left-handed from right-handed circularly polarized light (Chiou et al. 2008). Circularly polarized light arises when linearly polarized light travels through a birefringent material. Such material has different refractive indices for the $x$ - and the $y$-components of the evector, retarding one component with respect to the other (Land 2008). The resulting phase shift between the two components makes the e-vector rotate along the axis of the flight path, as the light travels through space. Importantly, only a material that retards one component by a quarter of the wavelength $\lambda$ (a $\lambda / 4$ retarder) generates circularly polarized light. If such light is again guided through a $\lambda / 4$ retarder, the $x$ - and $y$-components are shifted back into phase, and linearly polarized light results. It turned out that mantis shrimps possess caudal appendages which reflect patterns of circularly polarized light, and that the animals can be trained to distinguish between right-handed and lefthanded circular polarization. Chiou and colleagues discovered that one of the eight photoreceptors in certain ommatidia acts as $\lambda / 4$ retarder, turning circularly polarized light into linearly polarized light which is then analyzed by the remaining seven photoreceptors (Fig. 8a). The intricate architecture of the stomatopod eye provides the animal with two distinct channels of polarization vision and thus imparts additional visual qualities to the perception the environment.

Light polarization is not an exotic phenomenon to most of us, as we are used to polarizing filters on our cameras and our sunglasses, and the perception of light polarization appears to be just an additional aspect of vision. Magnetoreception, however, is a different matter. It is utterly amazing to observe the navigational skills of migratory animals

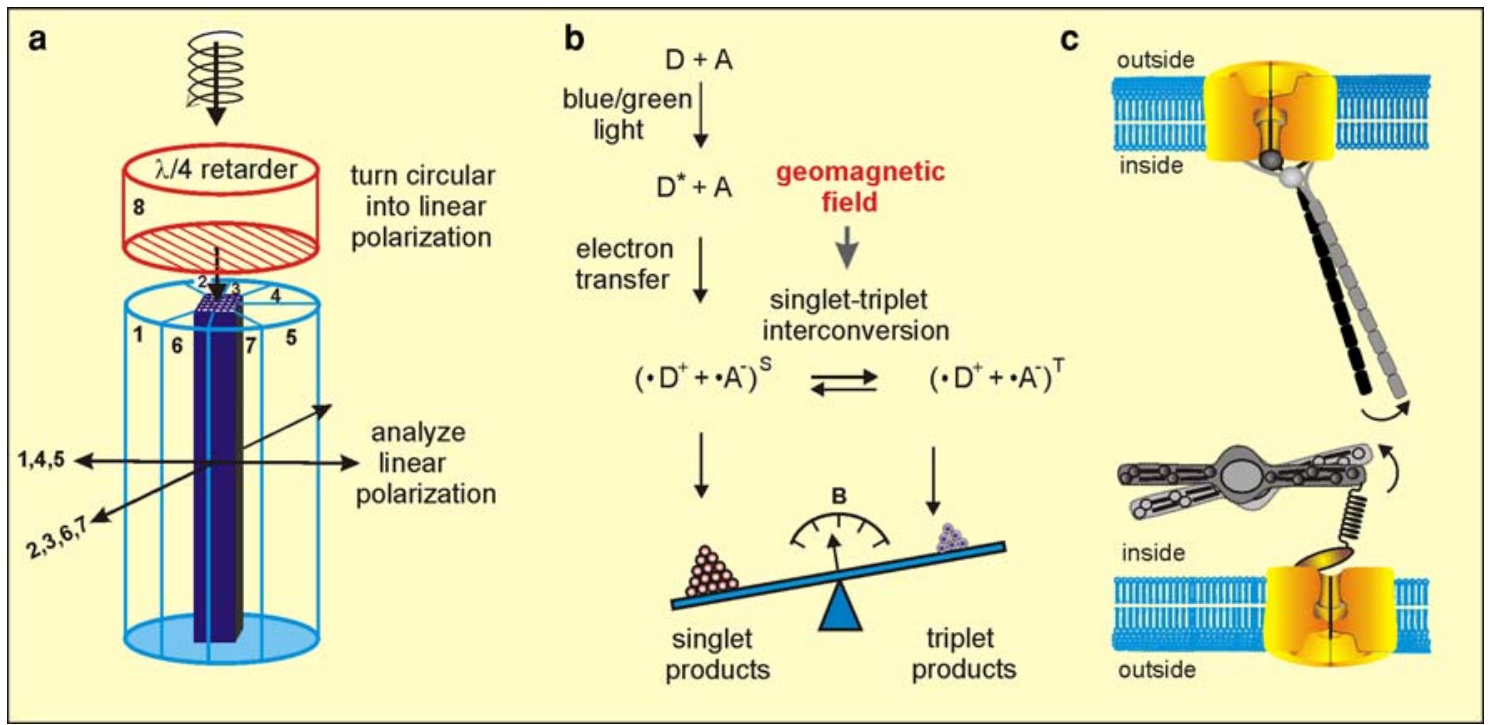

Fig. 8 Primary processes in polarization vision and magnetoreception a Schematic representation of circular-polarization vision in the mantis shrimp. Photoreceptor 8 is positioned in the light path that enters an ommatidium. The cell converts circularly polarized light into linearly polarized light. The remaining seven photoreceptors analyze the polarization plane. (changed from Chiou et al. 2008). b The radical pair model of magnetoreception. Two domains of a cryptochrome molecule act as electron donor (D) and acceptor (a), respectively. Upon light absorption, the donor reaches the excited state $\mathrm{D}^{*}$ and, subsequently, transfers an electron to the acceptor, giving rise to a radical pair in a spin-correlated singlet state $\left(\cdot \mathrm{D}^{+}+\cdot \mathrm{A}^{-}\right)^{\mathrm{S}}$. The yield of interconversions between the singlet and triplet states is affected by the geomagnetic field. The magnetosensory cell monitors the balance between singlet and triplet products as a measure of the magnetic field intensity B (changed from Ritz et al. 2000). $\mathbf{c}$ The magnetite hypothesis of magnetoreception. Top A chain of single-domain magnetite particles is connected to the gating mechanism of an ion channel. When the animal changes its position within the Earth's magnetic field, the chain is displaced and opens the channel. Bottom Small superparamagnetic magnetite particles are organized in plaques within the dendrite of a magnetosensitive neuron. These plaques consist of magnetite clusters (spheres) together with non-magnetic maghemite chains (black lines) around an iron-coated vesicle (center). The entire structure is thought to change its shape with its position in the geomagnetic field and to drive the gating mechanism of an ion channels through an elastic connection (changed from Solov'yov and Greiner 2007) 
and their use of magnetic cues. While human travellers need to be equipped with the Global Positioning System (GPS), a good map, a compass, and some geographic knowledge to find their way, animals apparently "see" or "feel" the geomagnetic field and know how to use the magneto-sensory perception to travel over long distances. Two questions have to be addressed for navigation: Where am I? And which direction leads to my destination? Interestingly, animals seem to use different sensory strategies to obtain these informations, involving different primary processes (Johnsen and Lohmann 2005; Mouritsen and Ritz 2005; Wiltschko and Wiltschko 2005, 2006, 2007). Animals can exploit at least three parameters of the magnetic field: the inclination of the magnetic field relative to the Earth's surface, and the direction to magnetic north, parameters that we obtain from an inclination compass and a declination compass, respectively. Moreover, animals perceive the local intensity of the geomagnetic field, a parameter that we determine using a magnetometer. In the search for the primary processes that transduce these parameters into neuronal signals, two models are currently favored, the radical pair model and the magnetite hypothesis. The radical pair model is based on the observations that certain modes of magnetoreception are light-dependent (Ritz et al. 2002), and that chemical free-radical reactions can be influenced by magnetic fields of $\leq 50 \mu \mathrm{T}$, the intensity of the geomagnetic field (Maeda et al. 2008). The candidate biomolecule for such a light-induced, magnetosensitive free-radical reaction is cryptochrome, a photopigment that is present in the retina of migratory birds (Möller et al. 2004) and was found to be necessary for magnetoreception in Drosophila (Gegear et al. 2008). Cryptochrome absorbs blue light and forms long-lived radical pairs (Liedvogel et al. 2007). The light-dependence of magnetoreception in birds has given rise to the notion that the impact of the magnetic field on cryptochrome photochemistry may represent a primary sensory process (Ritz et al. 2000, 2004; Beason 2005; Wiltschko and Wiltschko 2007). The idea is that cryptochrome forms a singlet radical pair upon illumination, and that the kinetics of singlet/triplet interconversion is affected by the geomagnetic field (Fig. 8b). The balance between singlet products and triplet products depends to some extent on the orientation of a cryptochrome-containing cell in the geomagnetic field. If a cryptochrome-containing cell is able to compare the amount of chemical products resulting from singlet pairs to that originating from triplet pairs, it can determine the yield of spin interconversion. Ritz et al. (2000) proposed that a visual representation of the magnetic field can result from an ordered distribution of cryptochrome-containing cells in the retina. While the radical pair model has not been established in all details, it represents a valuable hypothesis for directional magnetoreception in birds-it provides the molecular concept for a visual compass in the birds' eyes (Wiltschko and Wiltschko 2006).

But a compass alone does not bring you home if you do not know where you are. Thus, positional information is needed for navigation, information of the kind that we derive from comparing GPS readings with a map. Behavioral studies have revealed that migrating animals (birds, sea turtles, spiny lobsters) indeed possess positional information, and that this information is derived from the geomagnetic field (Lohmann et al. 2007). The inclination and the local intensity of the magnetic field supply useful positional information for large areas of the globe. For example, each location in the atlantic ocean has a unique combination of inclination and intensity, as the lines of equal field inclination (isoclinics) are oriented roughly eastto-west, while the lines of equal field intensity (isodynamics) run roughly north-to-south. Isoclinics and isodynamics thus form a grid on a magnetic map, just like latitudes and longitudes do on a geographic map. There is strong evidence that migratory animals can follow both isoclinics (Lohmann and Lohmann 2006) and isodynamics (Dennis et al. 2007) and, therefore, must have the ability to gain and process positional information. The primary processes underlying positional magnetoreception are thought to be distinct from the ones described by the radical pair model. The magnetite hypothesis was originally based on the microbiology of magnetotactic bacteria. These microorganisms contain strings of magnetite $\left(\mathrm{Fe}_{3} \mathrm{O}_{4}\right)$ particles, each of which has a size of $30-120 \mathrm{~nm}$, and is a stable, singledomain magnetic dipole (Blakemore 1982; Schüler 2008). The strings restrain thermal movements of the individual particles, so that their magnetic moments add up, and the entire string tends to align with the geomagnetic field, just like a compass needle. Animal physiologists have long speculated that magnetite particles may transduce geomagnetic signals in migratory animals (Kirschvink and Gould 1981; Kirschvink et al. 2001; Walker et al. 2002). Strings of permanently magnetic particles may be connected to the gating mechanism of an ion channel so that the magnetic field can trigger channel opening and generate a receptor potential (Fig. 8c). Indeed, single-domain magnetite particles were discovered in fish (Diebel et al. 2000), and indirect evidence points to a role of single-domain magnetite in magnetoreception by mole rats (Wegner et al. 2006) and bats (Holland et al. 2008). Curiously, the magnetite particles in various animals with robust magnetoreception are very small and are not aligned in orderly chains (e.g., homing pigeon; Fleissner et al. 2003). These particles have no stable magnetic moment, but they can assume a magnetic polarization in an applied field. An important recent finding is that such superparamagnetic material can, in principle, serve as a sensor in magnetosensory cells. Clusters of these particles change their shape when they are moved within a magnetic 
field (Fig. 8c). And the resulting forces are sufficient to gate ion channels (Fleissner et al. 2007; Hsu et al. 2007; Solov'yov and Greiner 2007). Thus, cryptochrome and magnetite may be the transducing molecules in directional and positional magnetoreception. This concept will be scrutinized and extended in the coming years with the still distant goal to understand magneto-electrical transduction in sensory neurons.

\section{Conclusions}

The data collected in this review illustrate several prominent similarities between primary processes of different sensory modalities:

(1) Stimulus detection: G-protein coupled receptors (GPCRs) detect a wide spectrum of chemical and visual stimuli. At least five families of GPCRs mediate chemosensory qualities and a number of rhodopsin varieties cover the visual and ultraviolet spectra. Mechanodetectors directly couple movement to the opening of transduction channels. (2) Transduction channels: most transduction channels belong to one of three protein superfamilies, die TRPs, the CNGs, and the degenerins. These are mostly non-selective cation channels, which are $\mathrm{Ca}^{2+}$-permeable and show little voltage dependence. Transduction channels are often components of a supramolecular protein complex that regulates channel activity. (3) Transduction complex: a large set of proteins may co-assemble to form a transduction complex. The considerable plasticity of a transduction complex may underly adaptation, sensitization, response kinetics, and noise reduction. (4) Amplification: primary receptor potentials may be amplified by prolonged activation of metabotropic receptors, by large electrochemical gradients for the receptor current, or by secondary currents that are conducted by distinct sets of ion channels.

These common principles may also apply to primary processes in sensory cells where transduction mechanisms are not yet understood.

Open Access This article is distributed under the terms of the Creative Commons Attribution Noncommercial License which permits any noncommercial use, distribution, and reproduction in any medium, provided the original author(s) and source are credited.

\section{References}

Ache BW, Young JM (2005) Olfaction: diverse species, conserved principles. Neuron 48:417-430

Adamek N, Coluccio LM, Geeves MA (2008) Calcium sensitivity of the cross-bridge cycle of Myolc, the adaptation motor in the inner ear. Proc Natl Acad Sci USA 105:5710-5715

Adler E, Hoon MA, Mueller KL, Chandrashekar J, Ryba NJP, Zuker CS (2000) A novel family of mammalian taste receptors. Cell 100:693-702
Ahmed ZM, Goodyear R, Riazuddin S, Lagziel A, Legan PK, Behra M, Burgess SM, Lilley KS, Wilcox ER, Riazuddin S, Griffith AJ, Frolenkov GI, Belyantseva IA, Richardson GP, Friedman TB (2006) The tip-link antigen, a protein associated with the transduction complex of sensory hair cells, is protocadherin-15. J Neurosci 26:7022-7034

Andersen JS, Mann M (2006) Organellar proteomics: turning inventories into insights. EMBO Rep 7:874-879

Araneda RC, Kini AD, Firestein S (2000) The molecular receptive range of an odorant receptor. Nat Neurosci 3:1248-1255

Ashmore J (2008) Cochlear outer hair cell motility. Physiol Rev 88:173-210

Au CE, Bell AW, Gilchrist A, Hiding J, Nilsson T, Bergeron JJM (2007) Organellar proteomics to create the cell map. Curr Opin Cell Biol 19:376-385

Avenet P, Lindemann B (1991) Noninvasive recording of receptor cell action potentials and sustained currents from single taste buds maintained in the tongue: the response to mucosal $\mathrm{NaCl}$ and amiloride. J Membr Biol 124:33-41

Bähner M, Frechter S, Da Silva N, Minke B, Paulsen R, Huber A (2002) Light-induced sub-cellular translocation of Drosophila TRPL channels induces long-term adaptation and modifies the light-induced current. Neuron 34:83-93

Bartel DL, Sullivan SL, Lavoie EG, Sevigny J, Finger TE (2006) Nucleoside triphosphate diphosphohydrolase-2 (NTPDase2) is the ecto-ATPase of type I cells in taste buds. J Comp Neurol 497:1-12

Batra-Safferling R, Abarca-Heidemann K, Körschen HG, Tziatzios C, Stoldt M, Budyak I, Willbold D, Schwalbe H, Klein-Seetharaman J, Kaupp UB (2006) Glutamic acid-rich proteins of rod photoreceptors are natively unfolded. J Biol Chem 281:1449-1460

Beason RC (2005) Mechanisms of magnetic orientation in birds. Integr Comp Biol 45:565-573

Behrens M, Foerster S, Staehler F, Raguse JD, Meyerhof W (2007) Gustatory expression pattern of the human TAS2R bitter receptor gene family reveals a heterogeneous population of bitter responsive taste receptor cells. J Neurosci 27:12630-12640

Behrens M, Meyerhof W (2006) Bitter taste receptors and human bitter taste perception. Cell Mol Life Sci 63:1501-1509

Bhandawat V, Reisert J, Yau KW (2005) Elementary response of olfactory receptor neurons to odorants. Science 308:1931-1934

Bianchi L (2007) Mechanotransduction: touch and feel at the molecular level as modeled in Caenorhabditis elegans. Mol Neurobiol 36:254-271

Blakemore RP (1982) Magnetotactic bacteria. Ann Rev Microbiol $36: 217-238$

Bleckmann H, Schmitz H, von der Emde G (2004) Nature as a model for technical sensors. J Comp Physiol A 190:971-981

Bounoutas A, Chalfie B (2007) Touch sensitivity in Caenorhabditis elegans. Pflügers Arch Eur J Physiol 454:691-702

Brown AL, Liao Z, Goodman MB (2008) MEC-2 and MEC-6 in the Caenorhabditis elegans sensory mechanotransduction complex: auxiliary subunits that enable channel activity. J Gen Physiol 131:605-616

Buck L, Axel R (1991) A novel multigene family may encode odorant receptors: a molecular basis for odor recognition. Cell 65:175187

Burns ME, Arshavsky VY (2005) Beyond counting photons: trials and trends in vertebrate visual transduction. Neuron 48:387-401

Calvert PD, Strissel KJ, Schiesser WE, Pugh EN, Arshavsky VY (2006) Light-driven translocation of signaling proteins in vertebrate photoreceptors. Trends Cell Biol 16:560-568

Caputi AA, Budelli R (2006) Peripheral electrosensory imaging by weakly electric fish. J Comp Physiol A 192:587-600

Caputo A, Caci E, Ferrera L, Pedemonte N, Barsanti C, Sondo E, Pfeffer U, Ravazzolo R, Zegarra-Moran O, Galietta LJV (2008) 
TMEM16A, a membrane protein associated with calcium-dependent chloride channel activity. Science 322:590-594

Chalfie M, Thomson JN (1982) Structural and functional diversity in the neuronal microtubules of Caenorhabditis elegans. J Cell Biol 93:15-23

Chandrashekar J, Hoon MA, Ryba NJP, Zuker CS (2006) The receptors and cells for mammalian taste. Nature 444:288-294

Chelur DS, Ernstrom GG, Goodman MB, Yao CA, Chen L, O'Hagan R, Chalfie M (2002) The mechanosensory protein MEC-6 is a subunit of the $C$. elegans touch cell degenerin channel. Nature 420:669-673

Chess A, Simon I, Cedar H, Axel R (1994) Allelic inactivation regulates olfactory receptor gene expression. Cell 78:823-834

Chiou T-H, Kleinlogel S, Cronin T, Caldwell R, Loeffler B, Siddiqi A, Goldizen A, Marshall J (2008) Circular polarization vision in a stomatopod crustacean. Curr Biol 18:429-434

Chyb S, Raghu P, Hardie RC (1999) Polyunsaturated fatty acids activate the Drosophila light-sensitive channels TRP and TRPL. Nature 397:255-259

Corey DP (2006) What is the hair cell transduction channel? J Physiol Lond 576:23-28

Corey DP (2007) Stringing the fiddle: the inner ear's two-part invention. Nat Neurosci 10:1232-1233

Corey DP, Hudspeth AJ (1979) Response latency of vertebrate hair cells. Biophys J 26:499-506

Corey DP, Hudspeth AJ (1983) Kinetics of the receptor current in bullfrog saccular hair cells. J Neurosci 3:962-976

Cuajungco MP, Grimm C, Heller S (2007) TRP channels as candidates for hearing and balance abnormalities in vertebrates. Biochim Biophys Acta 1772:1022-1027

Dallos P, Wu X, Cheatham MA, Gao J, Zheng J, Anderson CT, Jia S, Wang X, Cheng WHY, Sengupta S, He DZZ, Zuo J (2008) Prestin-based outer hair cell motility is necessary for mammalian cochlear amplification. Neuron 58:333-339

Dallos P, Zheng J, Cheatham MA (2006) Prestin and the cochlear amplifier. J Physiol 576:37-42

Damak S, Rong M, Yasumatsu K, Kokrashvili Z, Varadarajan V, Zou S, Jiang P, Ninomiya Y, Margolskee RF (2003) Detection of sweet and umami taste in the absence of taste receptor T1r3. Science 301:850-853

Damak S, Rong M, Yasumatsu K, Kokrashvili Z, Perez CA, Shigemura N, Yoshida R, Mosinger B, Glendinning JI, Ninomiya Y, Margolskee RF (2006) Trpm5 null mice respond to bitter, sweet, and umami compounds. Chem Senses 31:253-264

Danilova V, Damak S, Margolskee RF, Hellekant G (2006) Taste responses to sweet stimuli in $\alpha$-gustducin knockout and wild-type mice. Chem Senses 31:573-580

Delay ER, Hernandez NP, Bromley K, Margolskee RF (2006) Sucrose and monosodium glutamate taste thresholds and discrimination ability of T1R3 knockout mice. Chem Senses 31:351-357

Delmas P (2005) Polycystins: polymodal receptor/ion-channel cellular sensors. Pflügers Arch Eur J Physiol 451:264-276

Dennis TE, Rayner MJ, Walker MM (2007) Evidence that pigeons orient to geomagnetic intensity during homing. Proc R Soc B 274:1153-1158

Diebel CE, Proksch R, Green CR, Neilson P, Walker MM (2000) Magnetite defines a vertebrate magnetoreceptor. Nature 406:299-302

Drew LJ, Rohrer DK, Price MPP, Blaver KE, Cockayne DA, Cesare P, Wood JN (2004) Acid-sensing ion channels ASIC2 and ASIC3 do not contribute to mechanically activated currents in mammalian sensory neurons. J Physiol 556:691-710

Du H, Gu G, William CM, Chalfie M (1996) Extracellular proteins needed for C. elegans mechanosensation. Neuron 16:183-194

Dulac C, Kimchi T (2008) Neural mechanisms underlying sex-specific behaviors in vertebrates. Curr Opin Neurobiol 17:675-683
Dulac C, Wagner S (2006) Genetic analysis of brain circuits underlying pheromone signaling. Annu Rev Genet 40:449-467

Eatock RA (2000) Adaptation in hair cells. Annu Rev Neurosci 23:285-314

Elsaesser R, Montani G, Tirindelli R, Paysan J (2005) Phosphatidylinositide signalling proteins in a novel class of sensory cells in the mammalian olfactory epithelium. Eur J Neurosci 21:2692-2700

Emtage L, Gu G, Hartwieg E, Chalfie M (2004) Extracellular proteins organize the mechanosensory channel complex in C. elegans touch receptor neurons. Neuron 44:795-807

Fain GLF, Matthews HR, Cornwall MC, Koutalos Y (2001) Adaptation in vertebrate photoreceptors. Physiol Rev 81:117-151

Fettiplace R, Hackney CM (2006) The sensory and motor roles of auditory hair cells. Nat Rev Neurosci 7:19-29

Finger TE, Danilova V, Barrows J, Bartel DL, Vigers AJ, Stone L, Hellekant G, Kinnamon SC (2005) ATP signaling is crucial for communication from taste buds to gustatory nerves. Science 310:1495-1499

Firestein S, Picco C, Menini A (1993) The relation between stimulus and response in olfactory receptor cells of tiger salamander. J Physiol 468:1-10

Fleissner G, Holtkamp-Rötzler E, Hanzlik M, Winklhofer M, Fleissner G, Petersen N, Wiltschko W (2003) Ultrastructural analysis of a putative magnetoreceptor in the beak of homing pigeons. J Comp Neurol 458:350-360

Fleissner G, Stahl B, Thalau P, Falkenberg G, Fleissner G (2007) A novel concept of Fe-mineral-based magnetoreception: histological and physicochemical data from the upper beak of homing pigeons. Naturwiss 94:631-642

Friedrich RW (2006) Mechanisms of odor discrimination: neurophysiological and behavioral approaches. Trends Neurosci 29:40-47

Frolenkov GI (2006) Regulation of electromotility in the cochlear outer hair cell. J Physiol 576:43-48

Fu Y, Yau KW (2007) Phototransduction in mouse rods and cones. Pflügers Arch Eur J Physiol 454:805-819

Fukushige T, Siddiqui ZK, Chou M, Culotti JG, Gogonea CB, Siddiqui SS, Hamelin M (1999) MEC-12, an $\alpha$-tubulin required for touch sensitivity in C. elegans. J Cell Sci 112:395-403

Furness DN, Hackney CM (1985) Cross-links between stereocilia in the guinea pig cochlea. Hear Res 18:177-188

Furness DN, Katori Y, Kumar BN, Hackney CM (2008) The dimensions and structural attachments of tip links in mammalian cochlear hair cells and the effects of exposure to different levels of extracellular calcium. Neuroscience 154:10-21

Fuss SH, Omura M, Mombaerts P (2007) Local and cis effects of the $\mathrm{H}$ element on expression of odorant receptor genes in mouse. Cell 130:373-384

Gegear RJ, Casselman A, Waddell S, Reppert SM (2008) Cryptochrome mediates light-dependent magnetosensitivity in Drosophila. Nature 454:1014-1018

Gillespie PG, Cyr JL (2004) Myosin-1c, the hair cell's adaptation motor. Annu Rev Physiol 66:521-545

Gillespie PG, Dumont RA, Kachar B (2005) Have we found the tip link, transduction channel, and gating spring of the hair cell? Curr Opin Neurobiol 15:389-396

Goodman MB, Ernstrom GG, Chelur DS, O'Hagan R, Yao CA, Chalfie M (2002) MEC-2 regulates $C$. elegans $\mathrm{DEG} / \mathrm{ENaC}$ channels needed for mechanosensation. Nature 415:1039-1042

Gottlieb P, Folgering J, Maroto R, Raso A, Wood TG, Kurosky A, Bowman C, Bichet D, Patel A, Sachs F, Martinac B, Hamill OP, Honoré E (2008) Revisiting TRPC1 and TRPC6 mechanosensitivity. Pflügers Arch Eur J Physiol 455:1097-1103

Grant L, Fuchs PA (2007) Auditory transduction in the mouse. Pflügers Arch Eur J Physiol 454:793-804

Hamill OP, Martinac B (2001) Molecular basis of mechanotransduction in living cells. Physiol Rev 81:685-740 
Hamill OP (2006) Twenty odd years of stretch-sensitive channels. Pflügers Arch Eur J Physiol 453:333-351

Hardie RC (2007) Dynamic platforms. Nature 450:37-39

Heath TP, Melichar JK, Nutt DJ, Donaldson LF (2006) Human taste thresholds are modulated by serotonin and noradrenalin. J Neurosci 26:12664-12671

Heß M, Melzer RR, Eser R, Smola U (2006) The structure of anchovy outer retinae (Engraulididae, Clupeifomes)—a comparative light-and electron-microscopic study using museum-stored material. J Morphol 267:1356-1380

Hirota J, Omura M, Mombaerts P (2007) Differential impact of Lhx2 deficiency on expression of class I and class II odorant receptor genes in mouse. Mol Cell Neurosci 34:679-688

Holland RA, Kirschvink JL, Doak TG, Wikelski M (2008) Bats use magnetite to detect the Earth's magnetic field. PLoS ONE 3:e1676

Holton T, Hudspeth AJ (1986) The transduction channel of hair cells from the bull-frog characterized by noise analysis. J Physiol Lond 375:195-227

Homberg U (2004) In search of the sky compass in the insect brain. Naturwiss 91:199-208

Horváth G, Varjú D (2004) Polarized light in animal vision: polarization patterns in nature. Springer, Berlin

Hsu C-Y, Ko F-Y, Li C-W, Fann K, Lue J-T (2007) Magnetoreception system in honeybees (Apis mellifera). PLoS ONE 4:e395

Hu J, Milenkovic N, Lewin GR (2006) The high-threshold mechanotransducer: a status report. Pain 120:3-7

Huang AL, Chen X, Hoon MA, Chandrashekar J, Guo W, Tränkner D, Ryba NJP, Zuker CS (2006) The cells and logic for mammalian sour taste detection. Nature 444:934-938

Huang YJ, Maruyama Y, Dvoryanchikov G, Pereira E, Chaudari N, Roper SD (2007) The role of pannexin 1 hemichannels in ATP release and cell-cell communication in mouse taste buds. Proc Natl Acad Sci USA 104:6436-6441

Huang YA, Maruyama Y, Stimac R, Roper SD (2008) Presynaptic (type III) cells in mouse taste buds sense sour (acid) taste. J Physiol Lond 586:2903-2912

Huber A (2001) Scaffolding proteins organize multimolecular protein complexes for sensory signal transduction. Eur $\mathrm{J}$ Neurosci 14:769-776

Huber TB, Schermer B, Müller RU, Höhne M, Bartram M, Calixto A, Hagmann H, Reinhardt C, Koos F, Kunzelmann K, Shirokova E, Krautwurst D, Harteneck C, Simons M, Pavenstädt H, Kerjaschki D, Thiele C, Walz G, Chalfie M, Benzing T (2006) Podocin and MEC-2 bind cholesterol to regulate the activity of associated ion channels. Proc Natl Acad Sci USA 103:17079-17086

Hudspeth AJ (1982) Extracellular current flow and the site of transduction by vertebrate hair cells. J Neurosci 2:1-10

Hudspeth AJ (1989) How the ear's works work. Nature 341:397-404

Hummler E, Vallon V (2005) Lessons from mouse mutants of epithelial sodium channel and its regulatory proteins. J Am Soc Nephrol 16:3160-3166

Inada H, Kawabata F, Ishimaru Y, Fushiki T, Matsunami H, Tominaga M (2008) Off-response property of an acid-activated cation channel complex PKD1L3-PKD2L1. EMBO Rep 9:690-697

Ishii T, Omura M, Mombaerts P (2004) Protocols for two- and threecolor fluorescent RNA in situ hybridization of the main and accessory olfactory epithelia in mouse. J Neurocytol 33:657-669

Ishimaru Y, Inada H, Kubota M, Zhuang H, Tominaga M, Matsunami H (2006) Transient receptor potential family members PKD1L3 and PKD2L1 form a candidate sour taste receptor. Proc Natl Acad Sci USA 103:12569-12574

Jemth P, Gianni S (2007) PDZ domains: folding and binding. Biochem 46:8701-8708

Johnsen S, Lohmann KJ (2005) The physics and neurobiology of magnetoreception. Nat Rev Neurosci 6:703-712
Kachar B, Parakkal M, Kurc M, Zhao Y-d, Gillespie PG (2000) Highresolution structure of hair-cell tip links. Proc Natl Acad Sci USA 97:13336-13341

Kaissling KE (2001) Olfactory perireceptor and receptor events in moths: a kinetic model. Chem Sens 26:125-150

Kaneko H, Putzier I, Frings S, Kaupp UB, Gensch T (2004) Chloride accumulation in mammalian olfactory sensory neurons. J Neurosci 24:7931-7938

Kaneko H, Möhrlen F, Frings S (2006) Calmodulin contributes to gating control in olfactory calcium-activated chloride channels. J Gen Physiol 127:737-748

Kataoka S, Yang R, Ishimaru Y, Matsunami H, Sévigny J, Kinnamin JC, Finger TE (2008) The candidate sour taste receptor, PKD2L1, is expressed by type III taste cells in the mouse. Chem Senses 33:243-254

Kazmierczak P, Sakaguchi H, Tokita J, Wilson-Kubalek EM, Milligan RA, Müller U, Kachar B (2007) Cadherin 23 and protocadherin 15 interact to form tip-link filaments in sensory hair cells. Nature 449:87-92

Kellenberger S, Schild L (2002) Epithelial sodium channel/degenerin family of ion channels: a variety of functions for a shared structure. Physiol Rev 82:735-767

Kelliher KR, Spehr M, Li XH, Zufall F, Leinders-Zufall T (2006) Pheromonal recognition memory induced by TRPC2-independent vomeronasal sensing. Eur J Neurosci 23:3385-3390

Kimchi T, Xu J, Dulac C (2007) A functional circuit underlying sexual behavior in the female mouse brain. Nature 448:999-1000

Kinnamon JC, Henzler DM, Royer SM (1993) HVEM ultrastructural analysis of mouse fungiform taste buds, cell types, and associated synapses. Microsc Res Tech 26:142-156

Kirschvink JL, Gould JL (1981) Biogenic magnetite as a basis for magnetic field detection in animals. BioSystems 13:181-201

Kirschvink JL, Walker MW, Diebel CE (2001) Magnetite-based magnetoreception. Curr Opin Neurobiol 11:462-467

Kleene SJ (1997) High-gain, low-noise amplification in olfactory transduction. Biophys J 73:1010-1017

Kleene SJ, Gesteland RC (1981) Dissociation of frog olfactory epithelium with $N$-ethylmaleimide. Brain Res 229:536-540

Kleene SJ, Gesteland RC (1991) Calcium-activated chloride conductance in frog olfactory cilia. J Neurosci 11:3624-3629

Ko HJ, Park TH (2008) Enhancement of odorant detection sensitivity by the expression of odorant-binding proteins. Biosens Bioelectron 23:1017-1023

Körschen HG, Beyermann M, Müller F, Heck M, Vantler M, Koch KW, Kellner R, Wolfrum U, Bode C, Hofmann KP, Kaupp UB (1999) Interaction of glutamic-acid-rich proteins with the cGMP signalling pathway in rod photoreceptors. Nature 400:761-766

Kosloff M, Elia N, Joel-Almagor T, Timberg R, Zars TD, Hyde DR, Minke B, Selinger Z (2003) Regulation of light-dependent Gq alpha translocation and morphological changes in fly photoreceptors. EMBO J 22:459-468

Kozlov AS, Risler T, Hudspeth AJ (2007) Coherent motion of stereocilia assures the concerted gating of hair-cell transduction channels. Nat Neurosci 10:87-92

Krapp HG (2007) Polarization vision: how insects find their way by watching the sky. Curr Biol 17:R557-R560

Kriska G, Horváth G, Andrikovics S (1998) Why do mayflies lay their eggs en masse on dry asphalt roads? Water-imitating polarized light reflected from asphalt attracts Ephemeroptera. J Exp Biol 201:2273-2286

Kung C (2005) A possible unifying principle for mechanosensation. Nature 436:647-654

Kurahashi T, Yau KW (1993) Co-existence of cationic and chloride components in odorant-induced current of vertebrate olfactory receptor cells. Nature 363:71-74 
Lamb TD, Pugh EN (2004) Dark adaptation and the retinoid cycle of vision. Progr Retinal Eye Res 23:307-380

Lamb TD, Pugh EN (2006) Phototransduction, dark adaptation, and rhodopsin regeneration. Invest Ophthalmol Vis Sci 47:51385152

Land M (2008) Biological optics: circularly polarised crustaceans. Curr Biol 18:R348-R349

Laughlin JD, Ha TS, Jones DN, Smith DP (2008) Activation of pheromone-sensitive neurons is mediated by conformational activation of pheromone-binding protein. Cell 133:1137-1139

Lee SJ, Montell C (2004) Light-dependent translocation of visual arrestin regulated by the NINAC myosin III. Neuron 43:95-103

Leinders-Zufall T, Brennan P, Widmayer P, Chandramani P, MaulPavicic A, Jäger M, Li XH, Breer H, Zufall F, Boehm T (2004) MHC class I peptides as chemosensory signals in the vomeronasal organ. Science 306:1033-1037

Leinders-Zufall T, Lane AP, Puche AC, Ma W, Novotny MV, Shipley MT, Zufall F (2000) Ultrasensitive pheromone detection by mammalian vomeronasal neurons. Nature 405:792-796

Leinders-Zufall T, Cockerham RE, Michalakis S, Biel M, Garbers DL, Reed RR, Zufall F, Munger SD (2007) Contribution of the receptor guanylyl cyclase GC-D to chemosensory function in the olfactory epithelium. Proc Natl Acad Sci USA 104:14507-14512

Leung H-T, Tseng-Crank J, Kim E, Mahapatra C, Shino S, Zhou Y, An L, Doerge RW, Pak WL (2008) DAG lipase activity is necessary for TRP channel regulation in Drosophila Photoreceptors. Neuron 58:884-896

Leypold BG, Yu CR, Leinders-Zufall T, Kim MM, Zufall F, Axel R (2002) Altered sexual and social behaviors in trp2 mutant mice. Proc Natl Acad Sci USA 99:6376-6381

Li X, Li W, Wang H, Cao J, Maehashi K, Huang L, Bachmanov AA, Reed DR, Legrand-Defretin V, Beauchamp GK, Brad JG (2005) Pseudogenization of a sweet-receptor gene accounts for cats' indifference toward sugar. PLOS Genetics 1:e3

Li HS, Montell C (2000) TRP and the PDZ protein, INAD, form the core complex required for retention of the signalplex in Drosophila photoreceptor cells. J Cell Biol 150:1411-1421

Li HS, Porter JA, Montell C (1998) Requirement of the NINAC kinase/ myosin for stable termination of the visual cascade. J Neurosci 18:9601-9606

Liberles SD, Buck LB (2006) A second class of chemosensory receptors in the olfactory epithelium. Nature 442:645-650

Liedvogel M, Maeda K, Henbest K, Schleicher E, Simon T, Timmel CR, Hore PJ, Mouritsen H (2007) Chemical magnetoreception: bird cytochrome 1a is excited by blue light and forms long-lived radical pairs. PLoS ONE 10:e1106

Liman E (1999) TRP2: a candidate transduction channel for mammalian pheromone sensory signaling. Proc Natl Acad Sci USA 96:5791-5796

Liman E, Zufall F (2004) Transduction channels in the vomeronasal organ. In: Frings S, Bradley J (eds) Transduction channels in sensory cells. Wiley, Weinheim

Lin W, Finger TE, Rossier BC, Kinnamon SC (1999) Epithelial $\mathrm{Na}^{+}$ channel subunits in rat taste cells: localization and regulation by aldosterone. J Comp Neurol 405:406-420

Liu Q, Tan G, Levenkova N, Li T, Pugh EN, Rux JJ, Speicher DW, Pierce EA (2007) The proteome of the mouse photoreceptor sensory cilium complex. Mol Cell Proteomics 6:1299-1317

Lobanova ES, Finkelstein S, Song H, Tsang SH, Chen CK, Sokolov M, Skiba NP, Arshavsky VY (2007) Transducin translocation in rods is triggered by saturation of the GTPase-activating complex. J Neurosci 27:1151-1160

Löbel D, Jacob M, Völkner M, Breer H (2002) Odorants of different chemical classes interact with distinct odorant binding protein subtypes. Chem Sens 27:39-44
Lohmann KJ, Lohmann CMF (2006) Sea turtles, lobsters, and oceanic magnetic maps. Mar Freshw Behav Physiol 39:49-64

Lohmann KJ, Lohmann CMF, Putman NF (2007) Magnetic maps in animals: nature's GPS. J Exp Biol 210:3697-3705

Lomvardas S, Barnea G, Pisapia DJ, Mendelsohn M, Kirkland J, Axel R (2006) Interchromosomal interactions and olfactory receptor choice. Cell 126:403-413

LopezJimenez ND, Cavenagh MM, Sainz E, Cruz-Ithier MA, Battey JF, Sullivan SL (2006) Two members of the TRPP family of ion channels, $P k d 1 l 3$ and $P k d 2 l 1$, are co-expressed in a subset of taste receptor cells. J Neurochem 98:68-77

Lowe G, Gold GH (1993) Nonlinear amplification by calcium-dependent chloride channels in olfactory receptor cells. Nature 366:283-286

Lucas P, Ukhanov K, Leinders-Zufall T, Zufall F (2003) A diacylglycerol-gated cation channel in vomeronasal neuron dendrites is impaired in TRPC2 mutant mice: mechanism of pheromone transduction. Neuron 40:551-561

Luo D-G, Xue T, Yau K-W (2008) How vision begins: an odyssey. Proc Natl Acad Sci USA 105:9855-9862

Ma H, Yang R, Thomas SM, Kinnamon JC (2007) Qualitative and quantitative differences between taste buds of the rat and mouse. BMC Neurosci 8:5

Maeda K, Henbest KB, Cintolesi F, Kuprov F, Rodgers CT, Liddell PA, Gust D, Timmel CR, Hore PJ (2008) Chemical compass model of avian magnetoreception. Nature 453:387-391

Malnic B, Hirono J, Sato T, Buck LB (1999) Combinatorial receptor codes for odors. Cell 96:713-723

Marshall J, Cronin TW, Kleinlogel S (2007) Stomatopod eye structure and function: a review. Arthrop Struct Dev 36:420-448

Maruyama Y, Pereira E, Margolskee RF, Chaudari N, Roper SD (2006) Umami responses in mouse taste cells indicate more than one receptor. J Neurosci 26:2227-2234

Martinez-Salgado C, Benckendorff AG, Chiang L-Y, Wang R, Milenkovic N, Wetzel C, Hu J, Stucky CL, Parra MG, Mohandas N, Lewin GR (2007) Stomatin and sensory neuron mechanotransduction. J Neurophysiol 98:3802-3808

Matarazzo V, Zsürger N, Guillemot JC, Clot-Faybess O, Botto JM, Farra CD, Crowe M, Demaille J, Vincent JP, Mazella J, Ronin C (2002) Porcine odorant-binding protein selectively binds to a human olfactory receptor. Chem Sens 27:691-701

McLaughlin SK, McKinnon PJ, Margolskee RF (1992) Gustducin is a taste-cell-specific $\mathrm{G}$ protein closely related to the transducins. Nature 357:563-569

Meyer EP, Domanico V (1999) Microvillar orientation in the photoreceptors of the ant Cataglyphis bicolor. Cell Tissue Res 295:355361

Meyer NE, Joel-Almagor T, Frechter S, Minke B, Huber A (2006) Subcellular translocation of the eGFP-tagged TRPL channel in Drosophila photoreceptors requires activation of the phototransduction cascade. J Cell Sci 119:2592-2603

Meyerhof W (2008) Sour taste cells functionally identified. J Physiol Lond 586:2819

Mishra P, Socolich M, Wall MA, Graves J, Wang ZF, Ranganathan R (2007) Dynamic scaffolding in a G protein-coupled signaling system. Cell 131:80-92

Möller A, Sagasser S, Wiltschko W, Schierwater B (2004) Retinal cryptochrome in a migratory passerine bird: a possible transducer for the avian magnetic compass. Naturwiss 91:585-588

Molday RS (2007) ATP-binding cassette transporter ABCA4: molecular properties and role in vision and macular degeneration. J Bioenerg Biomembr 39:507-517

Mombaerts P (2004) Odorant receptor gene choice in olfactory sensory neurons: the one receptor-one neuron hypothesis revisited. Curr Opin Neurobiol 14:31-36 
Mombaerts P (2006) Axonal wiring in the mouse olfactory system. Annu Rev Cell Dev Biol 22:713-737

Montell C (2005) TRP channels in Drosophila photoreceptor cells. J Physiol 567:45-51

Montell C (2007) Dynamic regulation of the INAD signaling scaffold becomes crystal clear. Cell 131:19-21

Morrow IC, Parton RG (2005) Flotillins and the PHB domain protein family: rafts, worms and anaesthetics. Traffic 6:725-740

Mouritsen H, Ritz T (2005) Magnetoreception and its use in bird navigation. Curr Opin Neurobiol 15:406-414

Mueller KL, Hoon MA, Erlenbach I, Chandrashekar J, Zuker CS, Ryba NJP (2005) The receptors and coding logic for bitter taste. Nature 434:225-229

Müller U (2008) Cadherins and mechanotransduction by hair cells. Curr Opin Cell Biol 20:1-10

Nickell WT, Kleene NK, Kleene SJ (2007) Mechanisms of neuronal chloride accumulation in intact mouse olfactory epithelium. J Physiol 583:1005-1020

Nouvian R, Beutner D, Parsons TD, Moser T (2006) Structure and function of the hair cell ribbon synapse. J Membr Biol 209:153-165

O'Hagan R, Chalfie M (2006) Mechanosensation in Caenorhabditis elegans. Int Rev Neurobiol 69:169-203

O'Hagan R, Chalfie M, Goodman MB (2005) The MEC-4 DEG/ENaC channel of Caenorhabditis elegans touch receptor neurons transduces mechanical signals. Nat Neurosci 8:43-50

Okawa H, Sampath AP (2007) Optimization of single-photon response transmission at the rod-to-rod bipolar synapse. Physiology 22:279-286

Pace U, Hanski E, Salomon Y, Lancet D (1985) Odorant-sensitive adenylate cyclase may mediate olfactory reception. Nature 316:255-258

Park SP, Kim BM, Koo JY, Cho H, Lee CH, Kim M, Na HS, Oh U (2008) A tarantula spider toxin, GsMTx4, reduces mechanical and neuropathic pain. Pain 137:208-217

Pelosi P (2001) The role of perireceptor events in vertebrate olfaction. Cell Mol Life Sci 58:503-509

Pelosi P, Zhou JJ, Ban LP, Calvello M (2006) Soluble proteins in insect chemical communication. Cell Mol Life Sci 63:1658-1676

Perez CA, Huang L, Rong M, Kozak JA, Preuss AK, Zhang H, Max M, Margolskee RF (2002) A transient receptor potential channel expressed in taste receptor cells. Nat Neurosci 5:1169-1176

Pfeiffer K, Homberg U (2007) Coding of azimuthal directions via timecompensated combination of celestial compass cues. Curr Biol 17:960-965

Pickles JO (1985) Recent advances in cochlear physiology. Prog Neurobiol 24:1-42

Pickles JO, Cornis SD, Osborne MP (1984) Cross-links between stereocilia in the guinea pig organ of Corti, and their possible relation to sensory transduction. Hear Res 15:103-112

Pifferi S, Pascarella G, Boccaccio A, Mazzatenta A, Gustincich S, Menini A, Zucchelli S (2006) Bestrophin-2 is a candidate calciumactivated chloride channel involved in olfactory transduction. Proc Natl Acad Sci USA 103:12929-12934

Poetsch A, Molday LL, Molday RS (2001) The cGMP-gated channel and the related glutamic acid-rich proteins interact with perepherin-2 at the rim region of rod photoreceptor disc membranes. J Biol Chem 276:48009-480016

Ramsden SD, Anderson L, Mussi M, Kaamermans M, Hawryshyn CW (2008) Retinal processing and opponent mechanisms mediating ultraviolet polarization sensitivity in rainbow trout (Oncorhynchus mykiss). J Exp Biol 211:1376-1385

Ren T, Gillespie PG (2007) A mechanism for active hearing. Curr Opin Neurobiol 17:498-503

Reisert J, Bauer PJ, Yau KW, Frings S (2003) The Ca-activated Cl channel and its control in rat olfactory receptor neurons. J Gen Physiol 122:349-363
Reisert J, Lai J, Yau KW, Bradley J (2005) Mechanism of excitatory $\mathrm{Cl}$-response in mouse olfactory receptor neurons. Neuron 45:553-561

Reuter D, Zierold K, Schröder WH, Frings S (1998) A depolarizing chloride current contributes to chemoelectrical transduction in olfactory sensory neurons in situ. J Neurosci 18:6623-6630

Ricci AJ, Kachar B, Gale J, Van Netten SM (2006) Mechano-electrical transduction: new insights into old ideas. J Membr Biol 209:71-88

Richter TA, Caicedo A, Roper SD (2003) Sour taste stimuli evoke $\mathrm{Ca}^{2+}$ and $\mathrm{pH}$ responses in mouse taste cells. J Physiol 547:475-483

Ritz T, Adem S, Schulten K (2000) A model for photoreceptor-based magnetoreception in birds. Biophys J 78:707-718

Ritz T, Dommer DH, Phillips JB (2002) Shedding light on vertebrate magnetoreception. Neuron 34:503-506

Ritz T, Thalau P, Phillips JB, Wiltschko R, Wiltschko W (2004) Resonance effects indicate a radical-pair mechanism for avian magnetic compass. Nature 429:177-180

Roberts NW, Needham MG (2007) A mechanism of polarized light sensitivity in cone photoreceptors of the goldfish Carassius auratus. Biophys J 93:3241-3248

Romanov RA, Kolesnikov SS (2006) Electrophysiologically identified subpopulations of taste bud cells. Neurosci Lett 395:249-254

Roper SD (2007) Signal transductuion and information processing in mammalian taste buds. Pflügers Arch Eur J Physiol 454:759-776

Rothman A, Feinstein P, Hirota J, Mombaerts P (2005) The promotor of the mouse odorant receptor gene M71. Mol Cell Neurosci 28:535-546

Sanxaridis PD, Cronin MA, Rawat SS, Waro G, Acharya U, Tsunoda $S$ (2007) Light-induced recruitment of INAD-signaling complexes to detergent-resistant lipid rafts in Drosophila photoreceptors. Mol Cell Neurosci 36:36-46

Schroeder BC, Cheng T, Jan YN, Jan LY (2008) Expression cloning of TMEM16A as a calcium-activated chloride channel subunit. Cell 134:1019-1029

Schüler D (2008) Genetics and cell biology of magnetosome formation in magnetotactic bacteria. FEMS Microbiol Rev 32:654-672

Serizawa S, Miyamichi K, Nakatani H, Suzuki M, Saito M, Yoshihara Y, Sakano H (2003) Negative feedback regulation ensures the one receptor-one olfactory neuron rule in mouse. Science 302:20882094

Serizawa S, Miyamichi K, Sakano H (2004) One neuron-one receptor rule in the mouse olfactory system. Trends Genet 20:48-53

Shashar N, Hagan R, Boal JG, Hanlon RT (2000) Cuttlefish use polarization sensitivity in predation on silvery fish. Vision Res 40:71-75

Shigemura N, Ohkuri T, Sadamitsu C, Yasumatsu K, Yoshida R, Beauchamp GK, Bachmanov AA, Ninomiya Y (2008) Amiloride-sensitive $\mathrm{NaCl}$ taste responses are associated with genetic variation of ENaC $\alpha$-subunit in mice. Am J Physiol 294:R66-R75

Shin J-B, Adams D, Paukert M, Siba M, Sidi S, Levin M, Gillespie PG, Gründer S (2005) Xenopus TRPN1 (NOMPC) localizes to microtubule-based cilia in epithelial cells, including inner-ear hair cells. Proc Natl Acad Sci USA 102:12572-12577

Shoshan-Barmatz V, Zakar M, Shmuelivich F, Nahon E, Vardi N (2007) Retina expresses a novel variant of the ryanodine receptor. Eur J Neurosci 26:3113-3125

Sicard G, Holley A (1984) Receptor cell responses to odorants: similarities and differences among odorants. Brain Res 292:283-296

Sidi S, Friedrich R, Nicolson T (2003) NompC TRP channel required for vertebrate sensory hair cell mechanotransduction. Science 301:96-99

Siemens J, Lillo C, Dumont RA, Reynolds A, Williams DS, Gillespie PG, Müller U (2004) Cadherin 23 is a component of the tip link in hair-cell stereocilia. Nature 428:950-955

Smith DW, Thach S, Marshall EL, Mendoza MG, Kleene SJ (2008) Mice lacking NKCC1 have normal olfactory sensitivity. Physiol Behav 93:44-49 
Sokolov M, Lyubarsky AL, Strissel KJ, Savchenko AB, Govardovskii VL, Pugh EN, Arshavsky VY (2002) Massive light-driven translocation of transducin between the two major compartments of rod cells: a novel mechanism of light adaptation. Neuron 33:95106

Solov'yov IA, Greiner W (2007) Theoretical analysis of an iron mineral-based magnetoreceptor model in birds. Biophys J 93:14931509

Spehr M, Spehr J, Ukhanov K, Kelliher KR, Leinders-Zufall T, Zufall F (2006) Parallel processing of social signals by the mammalian main and accessory olfactory systems. Cell Mol Life Sci 63:1476-1484

Spors H, Wachowiak M, Cohen LB, Friedrich RW (2006) Temporal dynamics and latency patterns of receptor neuron input to the olfactory bulb. J Neurosci 26:1247-1259

Stauffer EA, Holt JR (2007) Sensory transduction and adaptation in inner and outer hair cells of the mouse auditory system. J Neurophysiol 98:3360-3369

Stauffer EA, Scarborough JD, Hirono M, Miller ED, Shah K, Mercer JA, Holt JR, Gillespie PG (2005) Fast adaptation in vestibular hair cells requires myosin-1c activity. Neuron 47:541-553

Sterling P, Matthews G (2005) Structure and function of ribbon synapses. Trends Neurosci 28:20-29

Stowers L, Holy TE, Meister M, Dulac C, Koentges G (2002) Loss of sex discrimination and male-male aggression in mice deficient for TRPC2. Science 295:1493-1500

Strissel KJ, Sokolov M, Trieu LH, Arshavsky VY (2006) Arrestin translocation is induced at a critical threshold of visual signaling and is superstoichiometric to bleached rhodopsin. J Neurosci 26:1146-1153

Stryer L (1986) Cyclic GMP cascade of vision. Annu Rev Neurosci 9:87-119

Sugita M (2006) Taste perception and coding in the periphery. Cell Mol Life Sci 63:2000-2015

Suzuki H, Kerr R, Bianchi L, Frokjaer-Jensen C, Slone D, Xue J, Gerstbrein B, Driscoll M, Schafer WR (2003) In vivo imaging of C. elegans mechanosensory neurons demonstrates a specific role for the MEC-4 channel in the process of gentle touch sensation. Neuron 39:1005-1017

Takeuchi H, Kurahashi T (2005) Mechanisms of signal amplification in the olfactory sensory cilia. J Neurosci 25:11084-11091

Talavera K, Yasumatsu K, Yoshida R, Margolskee RF, Voets T, Ninomiya Y, Nilius B (2008) The taste transduction channel TRPM5 is a locus for bitter-sweet taste interactions. FASEB J 22:13431355

Tavernarakis N, Driscoll M (2001) Mechanotransduction in Caenorhabditis elegans: the role of DEG/ENaC ion channels. Cell Biochem Biophys 35:1-18

Vandenbeuch A, Clapp TR, Kinnamon SC (2008) Amiloride-sensitive channels in type I fungiform taste cells in mouse. BMC Neurosci 9:1

Vollrath MA, Kwan KY, Corey DP (2007) The micromachinery of mechanotransduction in hair cells. Annu Rev Neurosci 30:339-365

Von der Emde G (2006) Non-visual environmental imaging and object detection through active electrolocation in weakly electric fish. J Comp Physiol A 192:601-612

Wachowiak M, Shipley MT (2006) Coding and synaptic processing of sensory information in the glomerular layer of the olfactory bulb. Semin Cell Dev Biol 17:411-423
Walker MM, Dennis TE, Kirschvink JL (2002) The magnetic sense and its use in long-distance navigation by animals. Curr Opin Neurobiol 12:735-744

Wang T, Montell C (2007) Phototransduction and retinal degeneration in Drosophila. Pflügers Arch Eur J Physiol 454:821-847

Wegner RE, Begall S, Burda H (2006) Magnetic compass in the cornea: local anaesthesia impairs orientation in a mammal. J Exp Biol 209:4747-4750

Wehner R (2001) Polarization vision-a uniform sensory capacity? J Exp Biol 204:2589-2596

Wehner R, Bernard GD (1993) Photoreceptor twist: a solution to the false-color problem. Proc Natl Acad Sci USA 90:4132-4135

Wes PD, Xu XZS, Li HS, Chien F, Doberstein SK, Montell C (1999) Termination of phototransduction requires binding of the NINAC myosin III and the PDZ protein INAD. Nat Neurosci 2:447-453

Wesson DW, Carey RM, Verhagen JV, Wachowiak M (2008) Rapid encoding and perception of novel odors in the rat. PLoS Biol 6:e82

Wetzel C, Hu J, Riethmacher D, Benckendorff A, Harder L, Eilers A, Moshourab R, Kozlenkov A, Labuz D, Caspani O, Erdmann B, Machelska H, Heppenstall PA, Lewin GR (2007) A stomatin-domain protein essential for touch sensation in the mouse. Nature 445:206-209

Wiltschko R, Wiltschko W (2006) Magnetoreception. BioEssays 28:157-168

Wiltschko W, Wiltschko R (2005) Magnetic orientation and magnetoreception in birds and other animals. J Comp Physiol A 191:675693

Wiltschko W, Wiltschko R (2007) Magnetoreception in birds: two receptors for two different tasks. J Ornithol 148:S61-S76

Yang YD, Cho H, Koo JY, Tak MH, Cho Y, Shim W-S, Park SP, Lee J, Lee B, Kim B-M, Rouf R, Shin YK, Oh U (2008) TMEM16A confers receptor-activated calcium-dependent chloride conductance. Nature. doi: $10.1038 /$ nature 07313

Yates JR, Gilchrist A, Howell KE, Bergeron JJM (2005) Proteomics of organelles and large cellular structures. Nat Rev Mol Cell Biol 6:702-714

Zhang S, Arnadottir J, Keller C, Caldwell GA, Yao CA, Chalfie M (2004) MEC-2 is recruited to the putative mechanosensory complex in C. elegans touch receptor neurons through its stomatinlike domain. Curr Biol 14:1888-1896

Zhang Y, Hoon MA, Chandrashekar J, Mueller KL, Cook B, Wu D, Zuker CS, Ryba NJP (2003) Coding of sweet, bitter, and umami tastes: different receptor cells sharing similar signaling pathways. Cell 112:293-301

Zhang Z, Zhao Z, Margolskee R, Liman E (2007) The transduction channel TRPM5 is gated by intracellular calcium in taste cells. J Neurosci 27:5777-5786

Zhao GQ, Zhang Y, Hoon MA, Chandrashekar J, Erlenbach I, Ryba NJP, Zuker CS (2003) The receptors for mammalian sweet and umami taste. Cell 115:255-266

Zheng J, Shen W, He DZZ, Long KB, Madison LD, Dallos P (2000) Prestin is the motor protein of cochlear outer hair cells. Nature 405:149-155

Zufall F, Ukhanov K, Lucas P, Leinders-Zufall T (2005) Neurobiology of TRPC2: from gene to behavior. Pflügers Arch Eur J Physiol 451:61-71

Zufall F, Leinders-Zufall T (2007) Mammalian pheromone sensing. Curr Opin Neurobiol 17:1-7 